Bond University

Research Repository

\title{
The Allconnex Water debacle: Lessons in devising better governance mechanisms for government business enterprises
}

\author{
Baumfield, Victoria
}

Published in:

Bond Law Review

Licence:

CC BY-NC-ND

Link to output in Bond University research repository.

Recommended citation(APA):

Baumfield, V. (2012). The Allconnex Water debacle: Lessons in devising better governance mechanisms for government business enterprises. Bond Law Review, 24(2), 1-63. https://blr.scholasticahq.com/article/5594

\section{General rights}

Copyright and moral rights for the publications made accessible in the public portal are retained by the authors and/or other copyright owners and it is a condition of accessing publications that users recognise and abide by the legal requirements associated with these rights.

For more information, or if you believe that this document breaches copyright, please contact the Bond University research repository coordinator. 


\section{Bond Law Review}

Volume 24 | Issue 2

Article 1

2012

The Allconnex Water Debacle: Lessons in Devising Better Governance Mechanisms for Government Business Enterprises

Victoria S. Baumfield

Bond University, vbaumfie@bond.edu.au

Follow this and additional works at: http://epublications.bond.edu.au/blr

This Article is brought to you by the Faculty of Law at ePublications@bond. It has been accepted for inclusion in Bond Law Review by an authorized administrator of ePublications@bond. For more information, please contact Bond University's Repository Coordinator. 


\title{
The Allconnex Water Debacle: Lessons in Devising Better Governance Mechanisms for Government Business Enterprises
}

\begin{abstract}
This article examines problems that occurred as a result of the Queensland government's restructuring of the State's water industry from 2006 onwards. It focuses on the experience on the Gold Coast, where the forced transfer of water retail and wastewater services from the Gold Coast City Council ('GCCC') to a regional water retailer, the Southern SEQDistributor-Retailer Authority, trading as Allconnex.

Water ('Allconnex'), was quickly followed by a large increase in the price of water, causing an extensive public outcry. Ultimately, the Queensland government was forced to grant city councils the option of resuming control over water from the new regional distributor-retailers. The GCCC voted to withdraw from Allconnex on 26 July 2011 and Allconnex ceased to exist on 1 July 2012.
\end{abstract}

\section{Keywords}

Allconnex, Queensland Water Commission, Queensland water, Queensland water governance, Queensland water distribution, Queensland water governance 


\title{
THE ALLCONNEX WATER DEBACLE: LESSONS IN DEVISING BETTER GOVERNANCE MECHANISMS FOR GOVERNMENT BUSINESS ENTERPRISES
}

\author{
VICTORIA SCHNURE BAUMFIELD*
}

\section{INTRODUCTION}

This article examines problems that occurred as a result of the Queensland government's restructuring of the State's water industry from 2006 onwards. It focuses on the experience on the Gold Coast, where the forced transfer of water retail and wastewater services from the Gold Coast City Council ('GCCC') to a regional water retailer, the Southern SEQ Distributor-Retailer Authority, trading as Allconnex Water ('Allconnex'), was quickly followed by a large increase in the price of water, causing an extensive public outcry. Ultimately, the Queensland government was forced to grant city councils the option of resuming control over water from the new regional distributor-retailers. The GCCC voted to withdraw from Allconnex on 26 July 2011 and Allconnex ceased to exist on 1 July 2012. ${ }^{1}$

The failure of this newly-created government business enterprise ('GBE') after a mere two years was undesirable for a number of reasons. ${ }^{2}$ The break-up costs alone were

* Senior Teaching Fellow, Bond University Faculty of Law, Gold Coast, Queensland, Australia. BA 1994, University of Pennsylvania; JD 1997, Columbia University. Member, New York Bar. The author wishes to thank Laurence Boulle, John Farrar, Patrick Keyzer, Kylie Fletcher-Johnson and the two anonymous referees for their useful comments and suggestions. This article is dedicated to the author's daughter, Alexandra. If it were not for Alexandra's birth in January 2011, the author would never have been home to watch this debacle play out over four months on the late afternoon Gold Coast News, and the spark that resulted in this article never would have been lit.

1 Regarding the GCCC vote see, eg, Daniel Hurst, 'Two Strikes and Allconnex Out', The Brisbane Times (online), 8 August $2011<\mathrm{http}$ //www.brisbanetimes.com.au/queensland/ two-strikes-and-allconnex-out-water-retailer-dumped-20110808-1iivz.htm>; see also Anna Bligh, 'Premier Says Enough Is Enough - Water Blame Game Ends' (Ministerial Media Statement, 7 April 2011). Regarding Allconnex's cession see South-East Queensland Water (Distribution and Retail Restructuring) and Other Legislation Amendment Act 2012 (Qld) s 23 (new ch 3A pt 2 to South-East Queensland Water (Distribution and Retail Restructuring Act 2009 (Qld)).

2 In this article the term 'government business enterprise' refers to all State-owned entities with a separate legal personality that engage primarily in commercial functions, including both public authorities and government owned corporations ('GOCs'). See 
estimated to be in the tens of millions of dollars or higher - a huge waste of the public's money. The nearly $\$ 30$ million cost of combining the three old water businesses became money down the drain, and all of the going-forward benefits of consolidation (eg, economies of scale) were similarly lost. ${ }^{3}$ Looking beyond the financial costs, the poor handling of this episode no doubt weakened trust in government officials to adequately safeguard the public interest, likely leading to knock-on effects including increased scepticism, cynicism and disengagement by the public towards future government initiatives. So it behoves policymakers and their advisers to study this episode to avoid repeating it.

This article aims to contribute towards that effort by examining what happened and what went wrong. As part of that examination, this article maps out the relevant laws and regulatory structures that applied to Allconnex and examines the role they may have played in Allconnex's demise, either by what they affirmatively required, or by what they failed to require. In particular, this article seeks to understand what factors contributed to the inability of Allconnex's stakeholders to devise a solution short of its destruction. It does so by examining Allconnex's corporate governance and pricing regimes. Deficiencies in both regimes are identified. In each case, the article suggests steps governments can take to avoid similar problems in the future, including changes to existing laws and regulations. This analysis is especially relevant since the other two distributor-retailers created along with Allconnex continue to exist.

More generally, this article illustrates the dangers of ignoring the extent to which GBEs are expected to act (or at least appear to act) in the public interest. ${ }^{4}$ Drawing from public trust theory, this article suggests ways that GBEs can be made more responsive to public concerns and, ultimately, accountable to the public for their conduct.

'Definition of Terms' in Berna Collier and Sally Pitkin (eds), Corporatisation and Privatisation in Australia (CCH Australia Ltd, 1999) xv, citing Administrative Review Council, The Contracting Out of Government Services, Issues Paper, AGPS, Canberra, February 1997, 'Glossary'.

3 See Robert MacDonald, 'Gold Coast City Council May Pay Dearly for Divorcing Allconnex as Water Retailer', The Courier-Mail (online), 15 August 2011 $<$ http://www.couriermail. com.au/news/opinion/gold-coast-city-council-may-pay-dearlyfor-divorcing-allconnex-as-water-retailer/story-e6frerdf-1226114738247>.

4 The author takes no position on whether Allconnex's management, including its board members, actually failed to take account of or act in the public interest. What is important is the public's perception of what Allconnex was doing, accurate or not. The public's perception was that Allconnex did not respect the needs and concerns of its monopoly customers. This led to the public outcry, which led to Allconnex's ultimate demise. 
The remainder of this article is structured as follows. Section II provides background information that is relevant to understanding what occurred. Specifically, Section II.A provides a summary of Queensland's water reforms, while Section II.B describes Allconnex's legal status and the laws and contracts that governed its conduct.

Section III discusses models of corporate governance and accountability in the public sector context, providing a schema for understanding Sections IV and V, which analyse the public and private sector governance and accountability regimes applicable to Allconnex.

Starting with the public sector framework, Section IV examines the extent to which Allconnex's conduct was restrained by administrative law remedies and other public sector-specific mechanisms, including the Ombudsman, freedom of information, and independent audit requirements.

Section V, in contrast, examines the extent to which standard corporate law accountability mechanisms, such as apply to private sector businesses, applied to Allconnex. Section V.A examines Allconnex's board structure and composition and the significance thereof from a corporate governance perspective. Section V.B examines the possibility that State or council-level officials could be liable as shadow directors. Section V.C examines the extent to which directors' duties applied to Allconnex's board. Sections V.D and E examine the critical questions of to whom such duties are owed, and to whom Allconnex's board was - and should have been accountable. Section V.F examines the remedies available for breach and who may enforce them. Section V.G, finally, examines the extent to which 'soft' law and selfregulation applied to Allconnex. Woven throughout Section V are suggestions for how these corporate law structures and mechanisms can be improved in the GBE context to make entities like Allconnex more responsive to public concerns and accountable for their conduct.

Section VI examines the critical question of pricing. Subsection VI.A discusses the lack of a legal requirement on Allconnex to keep prices as low as possible despite the fact that it was a monopoly supplier of a necessary good. 5 Subsection VI.B discusses the limited extent to which the Queensland Competition Authority could intervene in Allconnex's pricing. Subsection VI.C discusses steps that the Queensland Parliament and Allconnex finally took to limit price increases, and the problems with their approach. Section VII concludes by arguing that the creation of an overarching

5 Allconnex's provision of water and sewerage services was declared a monopoly business activity for purposes of s 20(1) of the Queensland Competition Authority Act 1997 (Qld): Queensland Competition Authority Regulation 2007 (Qld) reg 2A. Regulation 2A has since been repealed. 
obligation to consider the needs and concerns of the public may provide an important safety net allowing for GBEs to self-correct before it is too late.

\section{THE BACKgRound TO THE DispUte}

\section{A A Brief History of Queensland's Water Reforms}

For much of the first decade of the 2000s, the majority of Southeast Queensland ('SEQ') was subjected to a protracted, multi-year drought. In response, in 2006 the Queensland government instituted a package of water reforms with the stated goal of drought-proofing Queensland. ${ }^{6}$ Under the first part of the reforms, the State took over water assets that previously had been under control of local councils, including dams and other infrastructure. ${ }^{7}$ New entities - some public authorities and some government-owned-corporations - were created to engage in a variety of tasks related to water supply including:

- own all dams, groundwater infrastructure and water treatment plants in SEQ and accordingly catch, store and treat water by managing catchments, storages and water treatment plants; also supply water to SEQ Water Grid Manager (Seqwater);

- build new infrastructure including: water pipelines ('bulk water interconnections') connecting the region's various dams; a desalination plant; and a water recycling plant (Seqwater and Linkwater, which until January 2013 owned all the major pipelines in SEQ);

- manage the State's 'manufactured water' assets (ie, the desalination plant and the water recycling plant, which treats wastewater to make it usable again) (WaterSecure, merged into Seqwater on 1 July 2011);

- operate the new SEQ water grid and oversee the flow of water around the grid, including selling water to the distributor-retail entities (SEQ Water Grid Manager); and

- sell water and sewage services to the public (the three new distributorretailers, including Allconnex).

$6 \quad$ Queensland Water Commission, 'South-East Queensland Water Strategy' (15 July 2010) 77. Note: citations to the Queensland Water Commission ('QWC') documents originally included web addresses where the documents could be accessed on the QWC website. The QWC website was dismantled after the QWC was abolished on 1 January 2013, as discussed in Section VI.A below. Copies of QWC documents cited herein are on file with the author.

7 Ibid 79. 


\section{THE ALLCONNEX WATER DEBACLE}

The second part of the reforms took place on 1 July 2010 pursuant to the South-East Queensland Water (Distribution and Retail Restructuring) Act 2009 (Qld) (the '2009 Act'). It forced the consolidation of water retailing from individual city councils to new public entities called distributor-retailers, which were to be owned by clusters of local councils in geographic proximity to each other. So while the new regional water retailers were created by the State, they were technically owned not by the State but by the city councils whose water businesses the new entities were assuming.

The newly-created distributor-retailers were: Allconnex, which took over the water retail and wastewater service functions previously handled by the Gold Coast, Logan, and Redland City Councils; ${ }^{8}$ Queensland Urban Utilities (servicing the Brisbane, Scenic Rim, Ipswich, Somerset and Lockyer Valley areas); ${ }^{9}$ and Unitywater (servicing the Sunshine Coast and Moreton Bay areas). ${ }^{10}$ As the Queensland Water Commission explained the role of the new distributor-retailers: 'These entities own the water and sewerage distribution infrastructure and sell water and sewage disposal services to customers.'11 The 2009 Act provided that the distributor-retailers would last for 99 years, after which their assets and liabilities would revert to their participants. ${ }^{12}$ The participants theoretically were restricted to the participating councils, but the wording of the legislation leaves open the possibility that entities other than the councils (including perhaps privatised entities) could potentially become owners of the distributor-retailers at some point in the future. For example, s 22 of the 2009 Act states that a distributor-retailer's participation (ie, shareholder) agreement may provide for matters such as the issuing, registration, and transfer of participation rights (subject to ministerial approval) and the creation of different classes of participants.

On paper, the water reforms made sense. During the drought, the media had criticised the government for not having invested in additional infrastructure,

2009 Act ss 53AA-53AB (distributor-retailers became service providers 'for their geographic area functions' and 'each distributor-retailer's participating local government[] cease[d] to be a service provider'). See generally Water Supply (Safety and Reliability) Act 2008 (Qld) s 20 et seq (regarding service providers). As to the old regime, in which local governments were responsible for water supply and sewerage services, see the (now repealed) Sewerage and Water Supply Act 1949 (Qld) ss 3-4, and the regulations referred to therein.

9 Unitywater, Who We Are <http://unitywater.com/About-Us/Who-We-Are.aspx>.

10 Queensland Urban Utilities, Who We Are <http://www.urbanutilities.com.au/About_us/ Who_we_are/>.

11 Queensland Water Commission, above n 6, 25.

$12 \quad 2009$ Act s 10. 
including new dams and pipelines that could move supply from water rich regions to those in drought. At the same time, the proliferation of water entities suggested that cost savings could be had through consolidation. ${ }^{13}$ The water reforms 'reduced 21 entities down to just six businesses and the SEQ Water Grid Manager.' 14 The creation of economies of scale would seem to be a good thing for ratepayers. But Allconnex's experience shows that public concerns must not be ignored when implementing such large changes, no matter how wise the changes seem.

Within six months of taking over the three councils' water businesses, Allconnex raised prices by $20 \%$, infuriating customers and sparking a public outcry. ${ }^{15}$ Allconnex claimed that the increase was due to the State's decision to raise bulk water prices, but bulk water prices comprised only $25 \%$ of the increase. ${ }^{16}$ Accordingly, $75 \%$ of the price

13 Allconnex made this argument in response to the GCCC's announcement that it was withdrawing from Allconnex. It said there was no way that separate council water businesses could produce lower costs than Allconnex's economy of scale: see, eg, Petrina Berry, 'Councils Won't Do It Cheaper: Dumped Water Retailer', The Brisbane Times (online), 10 August $2011<$ http://www.brisbanetimes.com.au/environment/waterissues/councils-wont-do-it-cheaper-dumped-water-retailer-20110809-1ikn5.html>; 'Gold Coast Water Split From Allconnex Is 'Crazy' Says Minister', Courier Mail (online), 26 July $2011<$ http://www.couriermail.com.au/news/queensland/gold-coast-water-split-fromallconnex-is-crazy-says-minister/story-e6freoof-1226101871320>.

14 Stephen Robertson, 'New Framework Modernises Water Management in SEQ' (Ministerial Media Statement, 20 May 2010).

15 Matthew Killoran, 'Lower Water Prices 'Premature': Mayor', Gold Coast Bulletin (online), 28 January $2011<$ http://www.goldcoast.com.au/article/2011/01/28/287235_gold-coastnews. html>; Andrew Potts, 'Water Flip Won't Hit This Year's Budget', Gold Coast Sun (online), 14 April $2011<$ http://www.goldcoast.com.au/article/2011/04/14/307971_goldcoast-news-html>. Interestingly, according to the Queensland Competition Authority ('QCA'), prices had previously been increasing by $14-16 \%$ even when the local councils were still selling water. But price increases were not keeping pace with the councils' costs as the councils were subsidising water prices to keep them palatable to the public. For example, the QCA reported that 'the GCCC does not fully recover the costs of providing its retail water services, based on provided budget information.' According to the QCA's analysis, in 2009-2010, the GCCC was going to be imposing price increases of $14.40 \%$ for customers using $138 \mathrm{~kL}$ of water per year, and $16.22 \%$ for customers using $250 \mathrm{~kL}$ per year, which were both 'below the average price rise of $17.92 \%$ required to match revenue with costs': see QCA, 'Final Report: Retail Price Monitoring in SEQ Urban Water Sector - Gold Coast City Council' (Final Report, October 2009) 15-6.

16 Allconnex Water, 'Gold Coast Water Price Restructure to Benefit Water Savers' (Media Release, 25 March 2011); Queensland, Parliamentary Debates, Legislative Assembly, 14 February 2012, 64 (Christine Smith). As discussed in Section VI.A below, Allconnex was 


\section{THE ALLCONNEX WATER DEBACLE}

increase was within Allconnex's control and theoretically could have been contained had Allconnex management made the affordability of its product, a necessary good that all ratepayers must purchase, a priority. ${ }^{17}$ At the same time, Allconnex customers were unhappy about other aspects of the transition, including indications that Allconnex was perhaps not as prudent a steward of public funds as ratepayers, faced with sharply increased bills, would have liked. ${ }^{18}$ Whether Allconnex's attitude towards the public's funds was really as cavalier as members of the public believed is unclear and ultimately beside the point. The public perception was that Allconnex was unfairly raising prices to unaffordable levels, did not care about the impact those price increases had on its customers (a captive audience), and was making no effort to keep prices down, for example by restricting spending. That perception is ultimately all that mattered. Incensed customers took full advantage of modern communication technology, fanned by a sympathetic local media, to band together more efficiently than would have been possible in the past. ${ }^{19}$

The situation was becoming impossible for the council owners, who no longer ran their water businesses but were facing rising constituent anger at the situation. Eventually the participating city councils (in particular, the GCCC) were forced to act, for fear that councillors would lose their jobs over the issue. While the precise content of the conversations between the GCCC and Allconnex has not been reported, what seems clear is that the GCCC found itself in a standoff with Allconnex over the price increases. The GCCC apparently took the position that Allconnex could have raised prices less if it had wanted to, while Allconnex seems to have tried

legally required to fully pass on the cost of water (ie, the amount that Allconnex paid for bulk water purchases from the water wholesalers) to its customers.

17 Cf Allconnex Water, 'Infrastructure, Bulk Water Behind Water Price Increases' (Media Release, 8 February 2011) (attributing the rest of the price rise to 'a significant capital works program' and the need to deliver 'optimal returns on investment' to Allconnex's council-owners); see also Allconnex Water, 'Gold Coast Water Price Restructure to Benefit Water Savers', above n 16 (citing same two factors plus the need to fully reflect the true cost of providing water services).

18 See, eg, Potts, above n 15 (noting Allconnex's hiring of additional staff on high salaries and decision to move to expensive offices); Queensland, Parliamentary Debates, Legislative Assembly, 14 February 2012, 51 (Alex Douglas) (noting that Allconnex 'took long leases over very expensive premises', 'embarked on a $\$ 5$ million plus office fit-out', 'appointed a vast number of staff on very high remuneration and embarked on a wide media campaign').

19 See, eg, websites such as <http://www.goldcoastfightsallconnex.com.au/>; Melinda Siegmeier, 'Coast Water Protest to Raise the Roof', Gold Coast Bulletin (online), 26 February $2011<$ http://www.goldcoast.com.au/article/2011/02/26/295165_gold-coastnews.html>. 
to blame the councils, asserting that its price rises were partially a result of the councils' requirement that it maximise profits. ${ }^{20}$ Ultimately, the State government was forced to give the participating councils the choice to pull out of the distributorretailers, and the GCCC voted to do so on 26 July 2011, with Redland and Logan City Councils following in August 2011. ${ }^{21}$ As a result, those councils resumed control of their water businesses on 1 July 2012, on which date Allconnex was disestablished. ${ }^{22}$

\section{B Allconnex's Legal Status and Governing Documents}

The 2009 Act established three SEQ water distributor-retailer authorities, including the Southern SEQ Distributor-Retailer Authority, known as Allconnex. The hybrid and unique nature of the distributor-retailers' status bears emphasising. Despite having a commercial function as a water retailer and being viewed by the public as the 'water company', Allconnex (as well as the other two distributor-retailers) was neither a privatised company nor a government-owned corporation. Indeed, according to s 9 of the 2009 Act, Allconnex was 'not a body corporate'. ${ }^{23}$ Technically,

20 See, eg, Allconnex Water, 'Infrastructure, Bulk Water Behind Water Price Increases', above $\mathrm{n}$ 17. This requirement, which was set forth in $\mathrm{cl} 3(\mathrm{~d})$ of the Participation Agreement dated 25 June 2010 concluded by Allconnex and the Gold Coast, Logan, and Redland City Councils (the 'Participation Agreement'), is discussed in greater detail in Section VI.A, below. It should be noted that this account of what appears to have occurred is based on statements issued by the parties, stories reported in the media, and MPs' descriptions of what occurred during Parliamentary debates. The author would appreciate feedback by those involved if this description contains inaccuracies.

21 See, eg, Hurst, above n 1; see also Bligh, above n 1; Logan City Council, 'Council to Resume Control of Water in Logan' (Media Release, 23 August 2011) <http://www. logan.qld.gov.au/about-council/news-and-publications/media-releases/media-releases/ council-to-resume-control-of-water-in-logan>.

22 Queensland Water Commission, SEQ Water Reform (23 March 2012) <http://www. qwc.qld.gov.au/reform/index.html> (link no longer available but copy on file with the author); South-East Queensland Water (Distribution and Retail Restructuring) and Other Legislation Amendment Act 2012 (Qld) s 23 (new ch 3A pt 2 to the 2009 Act).

23 Perhaps this section was intended to prevent Allconnex from being considered a corporation for the purposes of the Corporations Act 2001 (Cth) ('Corporations Act'): see Corporations Act s 57A(1)(b) (defining 'corporation' to include 'any body corporate'). Section 9 further makes clear that a distributor-retailer 'is not constituted by its board or participants' (s 9(b)) and 'does not represent the State' (s 9(c)). Thus, the participating councils are technically not 'members' of the distributor-retailer. Nor does a distributorretailer enjoy 'the shield of the Crown' whereby its debts will be considered to be debts of the Crown under the Crown Proceedings Act 1980 (Qld): see Queensland Treasury Department, Statutory Body Guide: Guide Sheet 3 - Solvency (September 2010) 4-5 


\section{THE ALLCONNEX WATER DEBACLE}

it is probably best described as a public authority. Nevertheless, Allconnex was corporation-like: it 'ha[d] all the powers of an individual' including the power to enter into contracts; acquire, hold, dispose of, and deal with property; employ staff; appoint agents and attorneys; fix charges and other terms for services and other facilities it supplied; and do anything else necessary or convenient to be done for its functions. ${ }^{24}$

An interesting consequence of granting the distributor-retailers all the powers of an individual while deeming each of them 'not a body corporate' is that Parliament may have inadvertently caused them to be corporations for the purposes of the Corporations Act. Section 57A(1) of the Corporations Act defines 'corporation' to include '(c) an unincorporated body that under the law of its place of origin, may sue or be sued, or may hold property in the name of its secretary or of an office holder of the body duly appointed for that purpose.' Under s 15(5) of the 2009 Act, the distributor-retailers may sue and be sued, bringing them within s 57A(1)(c)'s definition. And while s 57A(2)(a) specifically excludes 'exempt public authorit[ies]' from the 'corporation' definition, the distributor-retailers are not 'exempt public authorit[ies]' since that definition only applies to body corporates, which the distributor-retailers are not. ${ }^{25}$ Therefore, although neither the distributor-retailers nor the Queensland government seem to be aware of this, the distributor-retailers appear to be subject to the portions of the Corporations Act that apply to corporations, although, as they are not companies, the distributor-retailers will not be subject to the many portions of the Corporations Act that apply only to the subset of corporations that are companies. ${ }^{26}$ This will be the case until and unless the Queensland

$<$ http://www.treasury.qld.gov.au/office/knowledge/docs/statutory-body-guide/statutorybody-guide-sheet-3.pdf $>$.

242009 Act s 12.

25 Compare Corporations Act s 9 ('exempt public authority means a body corporate that is incorporated within Australia ... and is: (a) a public authority') with 2009 Act s 9 (a distributor-retailer is 'not a body corporate').

26 As discussed in greater detail below, the portions of the Corporations Act that apply to all corporations, not just companies, include: the general directors' duties (ss 180-185); certain defences to claims of breach of duty (ie, s 189 (reliance)); the provisions dealing with the disqualification of directors (Part 2D.6); the provisions setting forth the civil consequences of contravening civil penalty provisions (eg, s 1317E et seq); and certain remedies (ie, injunctions under s 1324). The receivership provisions (but not the provisions dealing with voluntary administration and winding up) also refer to corporations rather than companies. Sections applicable only to companies (and, hence, not applicable to the distributor-retailers even if they are corporations for purposes of the Corporations Act) include: s 198A (the board's management power); Part 2D.3 
Parliament declares the statutory scheme creating the distributor-retailers to be an excluded matter pursuant to $\mathrm{s} 5 \mathrm{~F}$ of the Corporations Act. ${ }^{27}$ The ramifications of this discovery are explored in Section $\mathrm{V}$, below.

In addition to the foregoing, the 2009 Act provided that Allconnex was a statutory body for the purposes of the Statutory Bodies Financial Arrangements Act 1982 (Qld) and the Financial Accountability Act 2009 (Qld). ${ }^{28}$ As a statutory body, Allconnex was a separate legal entity despite not being a body corporate. ${ }^{29}$ It was an agency for the purposes of the Right to Information Act 2009 (Qld) and the Information Privacy Act 2009 (Qld). ${ }^{30}$ It was a unit of public administration for the purposes of the Crime and Misconduct Act 2001 (Qld) and 'a person authorised by law to provide a public utility service' for the purposes of the Land Act 1994 (Qld) and Land Title Act 1994 (Qld). ${ }^{31}$ Finally, Allconnex was a corporation for the purposes of the Penalties and Sentences Act 1992 (Qld). ${ }^{32}$ The same applies to the remaining two distributor-retailers.

As mentioned above, it appears that Parliament did not believe the Corporations Act provisions dealing with corporate governance matters such as directors' duties applied to the distributor-retailers. ${ }^{33}$ Accordingly, detailed rules as to the corporate

(appointment, remuneration and cessation of appointment of directors); Ch 2F (members' rights and remedies, including s 232 et seq (oppression) and s 236 et seq (statutory derivative actions)); and s 191 et seq (disclosure of, and voting on matters involving, material personal interests). In addition, the insolvent trading provisions (s 588G) do not apply to corporations that are not companies.

Parliament may thereby exclude either the entirety or specified provisions of the Corporations Act from applying to the distributor-retailers: see Corporations Act s 5F. 2009 Act ss 14-15.

29 Queensland Treasury Department, Statutory Body Guide: Guide Sheet 1 - Legislation, Policies and Guidance (June 2010) 1 <http://www.treasury.qld.gov.au/office/knowledge/docs/ statutory-body-guide/index.shtml $>$.

302009 Act ss 17-17A.

31 Ibid ss $16-18$.

32 Ibid s 18A.

33 See, eg, South-East Queensland Water (Distribution and Retail Restructuring) Regulation 2010 (Qld) ('2010 Regulations') reg 3(a) (stating that the regulations' main purpose was, inter alia, to provide 'for particular matters that the Corporations Act provides for corporations'); Queensland Department of the Premier and Cabinet, 'Welcome Aboard: A Guide for Members of Queensland Government Boards, Committees and Statutory Authorities' (July 2010) 12 <http://www.premiers.qld.gov.au/publications/categories/ policies-and-codes/ handbooks/welcome-aboard.aspx> (asserting that 'persons who are appointed to Government Boards which are not companies are not specifically bound by the Corporations $A c t^{\prime}$ ). Even if the distributor-retailers did not meet the definition of 'corporation,' arriving at the conclusion that the Corporations Act does not apply to them 


\section{THE ALLCONNEX WATER DEBACLE}

governance of the distributor-retailers were set forth in the South-East Queensland Water (Distribution and Retail Restructuring) Regulation 2010 (Q1d) ('2010 Regulations'). Ultimately, however, there is no great difference between the two. As discussed in greater detail in Section V.C below, which compares the 2010 Regulations with the Corporations Act, one of the 2010 Regulations' primary functions was to make certain sections of the Corporations Act applicable to the distributor-retailers, including the directors' duties found at ss 180-184 of the Corporations Act..$^{34}$ Indeed, most of the 2010 Regulations explicitly refer to analogous Corporations Act sections. ${ }^{35}$ Thus, in most areas where the Corporations Act applies to the distributor-retailers, there is no substantive variation between the substantive rules found in the Corporations Act and the rules governing directors' conduct that Parliament intended to apply. ${ }^{36}$

Further details as to how Allconnex was to be governed are contained in a Participation Agreement dated 25 June 2010, concluded by Allconnex and its three participating local governments (the Gold Coast, Logan, and Redland City Councils) as required by s 20 of the 2009 Act. ${ }^{37}$ In the case of any conflict between the Participation Agreement and the 2009 Act, the 2009 Act's provisions 'prevail[ed] to the extent of the inconsistency.' 38

is a less simple endeavour than one might imagine. Section $5 \mathrm{~A}$ of the Corporations Act ('Application to the Crown') specifies that certain parts of the Corporations Act apply to the Crown, including instrumentalities or agencies of the Crown, 'whether a body corporate or not'. But, upon inspection, the particular parts of the Corporations Act that apply to the Crown under s 5A are irrelevant for our purposes. In particular, they do not include $\mathrm{Ch} 2 \mathrm{D}$, which discusses, inter alia, the duties and powers of officers (including directors) and employees.

Regulation 3 of the 2010 Regulations lists two of the three 'main purposes' of the regulations as '(a) provid[ing], in relation to distributor-retailers, boards, officers or employees of distributor-retailers, for particular matters that the Corporations Act provides for corporations' and '(b) provid[ing] for a right to compensation for a contravention of a matter provided for under paragraph (a)'.

See 2010 Regulations reg 5.

The main divergence arises in the areas of remedies and enforcement: see Section V.F.

2009 Act s 20 required each distributor-retailer to enter into an agreement with its participating local governments about matters including profit-sharing, internal management, reporting requirements, and other matters as soon as practicable after the date of assent of the 2009 Act. A revised Participation Agreement was signed on 25 June 2011, and later amended to reflect the fact that Allconnex would be disestablished on 1 July 2012. That revised agreement will not be discussed in detail here. 


\section{The Challenge of Corporate Governance AND Accountability in the Public Sector Context}

This article proposes that defects in Allconnex's corporate governance structure were partially responsible for its demise. Corporate governance encompasses the mechanisms by which checks and balances are placed on corporate conduct. Whincop discusses the concept of 'corporate regulation ... focused on controlling the abuse of power and resources by those who manage the corporation.' ${ }^{39}$ As Farrar explains, corporate governance refers to 'the control of corporations and to systems of accountability by those in control.' 40 Control includes both legal and de facto control. Accountability encompasses not only legal restraints but also 'systems of self-regulation and the norms of so-called "best practice".'41

The concept of corporate governance can apply to organisations other than private sector corporations. ${ }^{42}$ The corporate governance of public sector entities has also been referred to by some as 'public sector governance'. ${ }^{33}$ Public sector entities, of course, including GBEs, have unique features that distinguish them from the usual shareholder-owned, board of director-managed business corporation. As the International Federation of Accountants Public Sector Committee observes:

[P]ublic sector entities have to satisfy a complex range of political, economic and social objectives, which subject them to a different set of external constraints. They are also subject to forms of accountability to various stakeholders, which are different to those that a company in the private sector has to its shareholders, customers, etc. The stakeholders in the public sector may include the Ministers, other government officials, the electorate (Parliament), customers and clients, and the general public, each with a

39 Michael J Whincop, Corporate Governance in Government Corporations (Ashgate, 2005) 63.

40 John Farrar, Corporate Governance: Theories, Principles and Practice (Oxford University Press, $3^{\text {rd }}$ ed, 2008) 3.

41 Ibid 4.

42 John Uhrig, 'Review of the Corporate Governance of Statutory Authorities and Office Holders' (Commonwealth of Australia, 2003); International Federation of Accountants Public Sector Committee, 'Corporate Governance in the Public Sector: A Governing Body Perspective ' (International Public Sector Study No 13, August 2001) 1.

43 See, eg, Meredith Edwards, 'Participatory Governance' (Corporate Governance ARC Project Issues Paper 6, University of Canberra, March 2008) 1; Simone Webbe and Pat Weller, 'A Public Interest Map: An Independent Review of Queensland Government Boards, Committees and Statutory Authorities' (Part A Report, December 2008) 28. 


\section{THE ALLCONNEX WATER DEBACLE}

legitimate interest in public sector entities, but not necessarily with any 'ownership rights'. ${ }^{44}$

Accordingly, perhaps a more appropriate conception of corporate governance for present purposes is that offered by the Audit Office of New South Wales:

Corporate governance issues include the way an organisation is structured, operated and controlled in order to achieve long term strategic goals and good customer and employee relations. In the public sector, corporate governance is also about how the Parliament, Government and boards relate to one another in stewardship matters. ${ }^{45}$

Accountability raises its own questions in the public sector entity context due to the variety of stakeholders and purposes that such an entity may serve. As Bottomley observes, 'accountability' can mean a variety of things including 'answerability, responsibility, efficient management, and adherence to the rule of law.' ${ }^{46}$ The 'unavoidable political reality', however, is that

a public bottom line ... expects 'the government' to be accountable for expenditure of public funds; exercise of public power and authority; and ultimately, for meeting the needs of the electorate who also happen to be customers of statutory authorities and other public bodies. The minister's capacity to use organisational form as a 'shield' in limiting ministerial responsibility beggars public acceptance. ${ }^{47}$

Traditionally, accountability was assumed to be ensured under the managerialist model, which focuses on the fact that GBE managers normally are ultimately accountable to ministers who are accountable to the public in a ministerial responsibility model characteristic of the Westminster system.

44 International Federation of Accountants Public Sector Committee, above n 42, 1.

45 Audit Office of NSW, 'Australian Performance Report: Public Sector Corporate Governance: Corporate Governance - Volume One: in Principle' (1997) 1.

46 Stephen Bottomley, 'Corporatisation and Accountability: the Case of Commonwealth Government Companies' (1997) 7 Australian Journal of Corporate Law 156, 159. The following discussion owes much to the useful analyses of Stephen Bottomley and the Hon Paul Finn. See also Stephen Bottomley, 'Regulating Government-Owned Corporations: A Review of the Issues' (1994) 53(4) Australian Journal of Public Administration 520; Stephen Bottomley, 'Government Business Enterprises and Public Accountability Through Parliament' (Research Paper 18 1999-2000, Parliament of Australia Parliamentary Library, 11 April 2000) <www.aph.gov.au/library/pubs/rp/19992000/2000rp18.htm>. As for Finn, see below n 49.

$47 \quad$ Webbe and Weller, above n 43, 34. 
In recent years GBE managers have been held accountable through a more robust variety of mechanisms than envisaged by the managerialist model, in particular, the administrative law procedures normally applicable to public sector entities. This reality reflects the influence of the public trust model, whose proponents 'begin[] from the proposition that government companies [and authorities] exercise public power and use public resources, and therefore ... should be subject to wider notions of trust and responsibility than their private sector counterparts.' ${ }^{48}$ These institutions and those who run them become in a sense, if not in actual law, the fiduciaries or trustees of the people. ${ }^{49}$ For, as the public trust model implicitly recognises, the members of the public at large are a GBE's true ultimate shareholders. ${ }^{50}$ Accordingly, it should be a given that GBEs must be concerned with the public interest. ${ }^{51}$

In light of the foregoing, the public trust model holds that GBEs should be accountable not only through ministerial responsibility, but also through other avenues including:

first, by direct accountability to members of the public (for example, through the courts and tribunals, and Freedom of Information legislation); secondly, by answering to 'accountability agencies' such as the Ombudsman, the Auditor General and parliament (especially through its standing committees); thirdly,

48 Bottomley, 'Corporatisation and Accountability', above n 46, 163-64. Bottomley quotes the 'WA Inc' Royal Commission Report (Western Australia, Royal Commission into Commercial Activities of Government and Other Matters, Report Part II (1992) [3.12.1]) as 'reject[ing] categorically the suggestion, behind which officials so often take refuge, that the "Westminster" derived principle of individual ministerial responsibility is a sufficient and effective external accountability measure': 164 .

Ibid 164, citing Paul Finn, 'The Abuse of Public Power in Australia: Making Our Governors Our Servants' (1994) 5 Public Law Review 43, 45. The Hon Paul Finn has written a number of useful articles examining the public trust theory at length. For a useful synopsis, see Paul Finn, 'The State Corporation' (1999) 3 Flinders Journal of Law Reform 1. For a longer treatment, see Paul Finn, 'Public Trust and Public Accountability' (1994) 3(2) Griffith Law Review 224.

50 See, eg, Hughes Aircraft Systems International v Airservices Australia (1997) 76 FCR 151, 196 (Finn J) ('The CAA, as I have noted is a public body - a body whose owners are, ultimately, the Australian community whom the authority serves under and in accordance with its statutory mandate.'). See also Whincop, above n 39, 7 (noting that, while 'the people' have 'little opportunity... to trade their interests', they are a GBE's 'residual claimants, as shareholders are in a [business corporation]').

51 See generally Whincop, above n 39, 162-63 (citing the 'publicness' of GOCs as a reason for considering the public interest as 'the criterion for action by, and in relation to' GOCs but expressing concern that difficulty in expressing the public interest might encourage the rise of interest group politics). 


\section{THE ALLCONNEX WATER DEBACLE}

through accountability of officers to superiors who are themselves accountable to accountability agencies (this includes the idea of Ministerial responsibility). ${ }^{52}$

As a public authority, Allconnex was generally subject to these mechanisms. In Allconnex's case, however, these public-sector specific accountability mechanisms were either insufficient to restrain the conduct at issue or simply inapplicable. The reasons for this are explained in detail in Section IV below.

The case of government-owned businesses, finally, raises questions as to the optimum level of government involvement with management. Much of the relevant literature raises concerns that active government oversight of GBEs can quickly devolve into improper interference with their boards. ${ }^{53}$ Interference is supposedly bad because, theoretically, one of the benefits of removing public sector businesses from the government's bosom is that independent operation and the introduction of a more competitive focus (including, for example, the requirement to cover its costs and ideally make a profit) will allow the business to maximise efficiency. This is equated with 'maximising welfare from the provision of services for a given level of taxation'. ${ }^{54}$ By implication, a business subject to government interference will be forced to sacrifice efficiency to satisfy the government's requirements, which will be infected by the desire to satisfy the demands of interest groups.

Efficiency, of course, equates not only to 'welfare' but to dollars. So maximising efficiency entails not only performing the business's service as well as or better than before, but at a lower cost. That is generally good, so long as reining in costs does not slide into dangerous corner-cutting. But in a commercially-oriented government business, efficiency also apparently entails maximising profits, which implies not merely reining in costs but also raising prices where the business can get away with

52 Bottomley, 'Corporatisation and Accountability', above n 46, 164, citing Western Australia, Royal Commission into Commercial Activities of Government and Other Matters, Report Part II (1992). Bottomley notes that '[t]he Royal Commission appears to have drawn heavily upon Finn's views, who was an adviser to the Royal Commission': at $164 \mathrm{n}$ 35. See also WB Lane and Simon Young, Administrative Law in Australia (Lawbook 2007) 293-94, 301-02.

53 See, eg, Farrar, above n 40, 467. See also Ross Grantham, 'The Governance of Government Owned Corporations' (2005) 23 Company and Securities Law Journal 181, 183, 189; Whincop, above $n$ 39, 9-10.

54 See, eg, Michael J Whincop, 'Another Side of Accountability: The Fiduciary Concept and Rent-Seeking in the Governance of Government Corporations' (2002) 25(2) University of New South Wales Law Journal 379, 380, 394. 
it. Accommodating the needs of particular users or stakeholders, resulting in less revenue to the GBE, is therefore a drag on efficiency and something to be avoided.

Whincop, for example, disparages the notion of segments of the public lobbying to have their interests taken into account by GBEs as rent-seeking, which in the law and economics world is, perhaps, the ultimate sin. In Whincop's view, rent-seeking is a 'problem' that is only beneficial to the extent that 'greater competition for rents between interest groups [may] minimise the deadweight costs of particular deals.' 55 In a perfect world, under this view, nothing would distract from 'pricing that maximises the surplus of revenue over costs. ${ }^{56}$ As a corollary, under this view, to minimise rent-seeking, less accountability to the public might be preferable to more. ${ }^{57}$

This article takes a different view, that it is appropriate, and indeed desirable, to understand and try to accommodate where possible the interests of the public. Certainly nobody wants government businesses to be inefficient; it is clearly better for the public if money is not wasted. However, it is not clear that 'maximising efficiency' in the sense of insulating GBEs from the need to consider the public's concerns will really lead to better overall welfare than allowing concerned segments of the public to be part of the process. For example, imagine that water consumers complained to the government about excessive price increases, and the governmentowner, in response, was able to direct the local water utility to reduce the price increases, ultimately decreasing the level of profits to be returned to the government as dividends. Under Whincop's view, this would be an example of improper rentseeking that caused total social welfare to decline since the water business made less money than it otherwise could have, leading to less money being returned to the government. The problem is that Whincop's analysis, while otherwise impressive, stops there. He does not consider the next step. What does the government actually do with the money that it receives from the water business? It will somehow spend it. It will do so in accordance with its policies and priorities, which themselves will have been shaped by the lobbying of interest groups. So rent-seeking will still ultimately

55 Ibid 395. Whincop defines 'rent-seeking' as 'any form of behaviour designed to redistribute in one's favour the rents associated with particular assets or enterprises - the surplus economic returns beyond those necessary to retain the asset in its use': at $381 \mathrm{n}$ 11. He notes that ' $[r]$ ent-seeking can readily occur in private relations, for example, where one party makes an opportunistic threat not to perform a contract unless the gains from trade are redistributed. However, the term is also commonly used in the context of public choice theory, where it describes the behaviour of interest groups who seek legislation or other political acts that redistributes [sic] income and assets in their favour.'

$57 \quad$ Ibid 381. 
determine who benefits from these funds, just at the governmental level instead of the GBE level. The GBE's profits enter the black box of government where they are intermingled with the rest of the government's funds and become available to fund those who succeed at the political process. So the struggling single mother whose water bill just rose $20 \%$ could be subsidising big corporations and other entities powerful enough to be able to lobby successfully. Does that really lead to greater public welfare than simply charging less for water? Worse, because of the fungibility of the dollar, it is not even clear where the profits collected by the government from GBEs actually go. At least if concerned segments of the public are accommodated during the GBE's decision-making process, there is greater transparency about who the winners and losers are. It is clear who is subsidising whom.

In Allconnex's case, it appears that more active involvement from government entities holding the power to influence Allconnex's management decisions would have been beneficial. Both State and local government officials eventually took steps in response to the public outrage over Allconnex's behaviour. It was that outrage, of course, that ultimately caused Allconnex to be shut down. If mechanisms had been in place to allow the government, particularly at the council-owner level, to get involved sooner, perhaps Allconnex's approach could have been modified before public anger grew so overwhelming that there was politically no way forward other than to shut it down.

\section{The Role of Accountability Mechanisms Specific to Public SECTOR ENTITIES}

As a public authority, Allconnex, like the other distributor-retailers, was subject to a number of administrative law accountability mechanisms. This section discusses why those mechanisms, including detailed audit and reporting requirements, freedom of information legislation, and the oversight of an industry Ombudsman, were insufficient to save Allconnex.

\section{A The Ombudsman}

In Queensland, the water and energy industries have their own dedicated ombudsman, ${ }^{58}$ who has the power to issue binding determinations on matters brought to his or her attention. ${ }^{59}$ The Ombudsman's powers are relatively robust,

\footnotetext{
58 See the Energy and Water Ombudsman Act 2006 (Qld). With respect to water, the Ombudsman has jurisdiction over 'water entities', which are now defined as distributorretailers or 'withdrawn councils', ie, Allconnex's former owners: s 7A. 
including the power to require water retailers not to impose disputed charges and even to compensate the complaining customer. ${ }^{60}$ However, the Water Ombudsman's ability to affect water pricing is limited: s 12A of the Energy and Water Ombudsman Act 2006 forbids the Ombudsman from 'accept[ing] a referral about or investigat[ing] the fixing of (a) charges for wastewater services or water services; or (b) methodologies for fixing the charges.' Moreover, s 12B forbids the Ombudsman from accepting a referral about or investigating the content of government policies, the customer water and wastewater code, and the like. Therefore, the most that the Ombudsman can do in this area, in line with its functions as set out in s 11 of the Act, is 'identify systemic issues arising out of complaints anyone makes to the Ombudsman', including keeping track of rejected complaints involving pricing.

\section{B Freedom of Information/Disclosure}

Traditional corporate law makes companies - especially large public companies subject to extensive disclosure obligations, such as the need to file annual reports. Disclosure aids good corporate governance by enabling interested parties to observe and react to an entity's conduct. Access to information is similarly critical to ensuring the accountability of public sector institutions, ${ }^{61}$ and is ensured through freedom of information and other disclosure obligations.

In Allconnex's case, the 2009 Act made clear that the distributor-retailers not only are subject to Queensland's Right to Information Act 2009 but have additional specific obligations to make key information publicly available. ${ }^{62}$ In particular, Allconnex was required to provide key documents on its website. The distributor-retailers are also subject to the Financial Accountability Act 2009 (Qld) ('FAA'), ${ }^{63}$ which, among other things, requires statutory bodies to provide their relevant minister with annual

$60 \quad$ Ibid s 35.

61 See, eg, Lane and Young, above n 52, 293.

62 See, eg, 2009 Act s 17 (Allconnex is subject to the Right to Information Act 2009 (Qld)); s $30 \mathrm{~A}$ (requiring Allconnex and its local government owners to publish the Participation Agreement, and any amendments thereto, on their websites within 30 days of its taking effect); s 99ATA (Allconnex must publish its charges on its website); ch 5 pt 1 (ss 99BT99BV) (providing for public access to certain Allconnex documents including its capital works program, 'a map showing the limits of the distributor-retailer's connection areas', and 'each infrastructure agreement to which the distributor-retailer is a party').

63 Ibid s 15(1) (confirming the applicability of the FAA to the distributor-retailers). Pursuant to $F A A$ s 57, the distributor-retailers are also required to comply with the Financial and Performance Management Standard 2009 (Qld). 


\section{THE ALLCONNEX WATER DEBACLE}

reports. ${ }^{64}$ That minister is then required to 'table the annual report in the Legislative Assembly' ${ }^{65}$ As is normal in these circumstances, the minister, at the request of a distributor-retailer's board, may delete information about commercially sensitive matters from its annual report before providing it to Parliament and the public. ${ }^{66}$ However, the minister should keep in mind that Queensland's current freedom of information regime is pro-disclosure in spirit. ${ }^{67}$ In any event, Allconnex published its two Annual Reports on its website, seemingly with no redactions. ${ }^{68}$

\section{Independent Audit Requirements}

The requirement to be audited by an independent legislative auditor such as an auditor-general is a standard control mechanism for public sector entities, ${ }^{69}$ just as the existence of an independent audit process is viewed as a positive sign when evaluating a company's corporate governance regime. ${ }^{70}$ In the distributor-retailers' case, they must prepare annual financial statements, have them audited by Queensland's Auditor-General, and include them in the annual report to be provided to the portfolio minister each year. ${ }^{71}$ However, this audit requirement was irrelevant to the matters at issue in the Allconnex dispute because the annual financial statement audit is focussed on the correctness of the entities' financial statements,

64 The distributor-retailers are statutory bodies for purposes of the FAA: 2009 Act s 15(1). As to reporting, see FAA s 63(1). Allconnex's Participation Agreement also required it to provide quarterly reports and a copy of the audited annual report to the participating councils: Participation Agreement $12 \mathrm{cl} 7.1$.

65 FAA s 63(2).

662009 Act s 19. Such commercial exceptions to disclosure requirements are common in freedom of information legislation: see, eg, Lane and Young, above n 52, 326-27 [4.80].

67 See, eg, Right to Information Act 2009 (Qld) s 44 (stating Parliament's intention that the Act be administered with a pro-disclosure bias and confirming that 'an agency or Minister may give access to a document even if this Act provides that access to the document may be refused'); s 47 (the grounds for refusing access to a document 'are to be interpreted narrowly').

68 The materials posted on Allconnex's website were removed when Allconnex was disestablished. Copies of such materials cited herein are on file with the author.

69 See, eg, International Federation of Accountants Public Sector Committee, above n 42, 6-7.

70 Bob Tricker, Corporate Governance: Principles, Policies, and Practices (Oxford University Press, 2009) 322-25.

$71 \quad F A A \mathrm{~s} 62$. 
including the application of the correct accounting standards, not on the wisdom of the entity's pricing model. ${ }^{72}$

In addition, the distributor-retailers may be subject to performance audits in which the Auditor-General decides 'whether the objectives of the public sector entity are being achieved economically, efficiently and effectively and in compliance with all relevant laws.' 73 In a performance audit, the Auditor-General may audit 'all or any particular activities of a public sector entity', ${ }^{74}$ including pricing. Performance audits are useful because they can look behind the numbers into the substance of how a GBE is operating. For example, a performance audit of Allconnex's pricing policy could have examined the components of the mark-up that Allconnex charged on top of the price at which it purchased water from the grid and evaluated the extent to which Allconnex's retail prices were inflated due to excessive spending on things within Allconnex's control, such as salaries and rent. Such an audit could also have considered the extent to which a decision to remit lower profits to the owner-councils would have enabled Allconnex to charge lower prices.

It appears that Allconnex was never subject to such a performance audit during its short life. Even if it had been, however, the performance audit likely would not have found fault with Allconnex's pricing mechanisms since these audits are concerned with efficiently achieving an entity's objectives, which, in Allconnex's case, did not include maintaining affordable prices for consumers. To the contrary, one of Allconnex's formal objectives was to deliver 'optimal returns' to its shareholders. Therefore, there would have been no basis for such an audit to be critical on the ground that prices were higher than necessary even if information uncovered during the audit could have justified such a conclusion.

\section{Requirements to Consult During the Strategic Planning Process}

Accountability of public agencies may also be obtained through forward planning requirements that mandate consultation with entities such as the relevant portfolio minister. Indeed, Allconnex was required to consult with its council owners as part of its strategic planning process. ${ }^{75}$ However, this consultation requirement was weakened by the fact that the council-owners did not have a veto power over Allconnex's proposals. This point is discussed in greater detail in Section V.E below,

$72 \quad$ Financial and Performance Management Standard 2009 (Qld) ss 42-43; Queensland Treasury Department, 'Financial Reporting Requirements for Queensland Government Agencies' (March 2012).

73 Auditor-General Act 2009 (Qld) s 37A(3).

74 Ibid s 37A(1).

75 Participation Agreement 10 cl 6.1(b)(i). 


\section{THE ALLCONNEX WATER DEBACLE}

which discusses to whom Allconnex's board members were accountable and to what extent.

\section{E Oversight by Competition Regulators}

GBEs with monopoly power may be held accountable for their pricing decisions by the QCA. Indeed, Allconnex was required to submit detailed information justifying its pricing to the QCA. But, again, the scope of the QCA's power simply did not extend to the policy question of determining whether Allconnex should have taken more heed of the public's reaction to its pricing strategy and charged less than the law allowed. This point is discussed in more detail in Section VI.B below.

\section{F Judicial Review}

Because they are public authorities, the distributor-retailers' administrative decisions are in some instances subject to review by the Queensland Civil and Administrative Tribunal ('QCAT'). ${ }^{76}$ But QCAT's jurisdiction over the distributor-retailers only extends to the review of decisions to give work directions, discharge compliance notices, and make consistency amendments of trade waste approvals. ${ }^{77}$ Accordingly, appeals of pricing decisions could not have been made to QCAT. Such decisions might be amenable to judicial review if appropriate grounds can be made out, such as that the making of the decision was an improper exercise of the power conferred by the enactment under which it was purported to be made. ${ }^{78}$ It is beyond this article's scope to provide a detailed exposition on the judicial review of administrative action in Queensland or elsewhere. Suffice it to say that it likely would be extremely challenging to convince a court that any such grounds apply to overturn a distributor-retailer's pricing determination.

\section{G The Role of Politics}

Where the public is unhappy about the conduct of a government-owned entity, political pressure is always an option. Such pressure is most likely to be effective when politicians (a) have reason to think that the issue might ultimately take a significant role in the next election (meaning that the politician might actually lose his or her job over it) and (b) have the ability, one way or another, to impose their will on the GBE. If politicians cannot actually do anything about the problem, then political pressure will be useless.

76 Queensland Civil and Administrative Tribunal, Review of Administrative Decisions (27 March 2012) <http://www.qcat.qld.gov.au/matter-types/review-of-administrativedecisions $>$.

772009 Act s 100D.

78 See Judicial Review Act 1991 (Qld) ss 20(2), 23. 
In this case, it was indeed political pressure that was ultimately the most effective restraint on Allconnex's conduct, when it became clear that citizen anger at Allconnex was not going to fade. Politicians became fearful for their jobs and so both local and State politicians eventually took action. The State gave councils the opportunity to withdraw from their distributor-retailers, and, in Allconnex's case, the councils took up the offer. Ironically, the consumer anger could have been dampened, avoiding the need to offer councils the right to withdraw and preserving Allconnex, if the State had executed the other step that it eventually took - enacting legislation restricting Allconnex's ability to raise prices to the consumer price index in a timelier manner. The belated imposition of price controls is discussed in greater detail in Section VI.C below.

The fact that politicians eventually responded to the public's message could potentially be viewed as the triumph of the ministerial responsibility model, but such a view would be wrong. According to that model, Allconnex should have heeded the public outcry and taken steps to rein in its price increases before the politicians ever got involved, since Allconnex should have known that it would eventually be called to account by its political masters. But Allconnex remained intransigent until customer anger had solidified to such an extent that the GCCC essentially had no choice but to withdraw, causing Allconnex's demise. This can hardly be called a successful outcome, considering the benefits that a properly managed Allconnex would have allowed the community to enjoy.

Furthermore, it is never a given that political pressure will be effective. Political pressure is a useful adjunct to the other accountability tools, but is too uncertain to be relied upon on its own. The extent to which public pressure may be an effective constraint on GBE conduct is discussed in more detail in Section VF below.

\section{The Applicability of Standard Corporate Governance Mechanisms to Allconnex}

The previous section considered the role of administrative law remedies and other mechanisms particular to public sector institutions in holding Allconnex accountable to the public. This section considers the extent to which corporate law principles applicable to private sector businesses may constrain the conduct of Allconnex and other GBEs. It focuses on the role and composition of GBE boards, board members' duties, enforcement of breach, and remedies. This section also considers the role of 'soft' law and self-regulation in the governance of GBEs. This section's analysis reveals that as yet untapped opportunities still exist to restore a public focus to GBEs and ensure GBE accountability to their ultimate conceptual owners, the public. Accordingly, interwoven into this section are ideas and proposals on how this can be 


\section{THE ALLCONNEX WATER DEBACLE}

accomplished, including, perhaps most radically, the creation of a duty to consider the interests of the public similar in concept to s 172 of the Companies Act 2006 (UK).

\section{A The Board of Directors: Its Role and Composition}

Board oversight constrains management. Directors' duties attempt to reduce agency costs associated with having non-owners (the board) supervising company management by ensuring that the board itself acts appropriately. ${ }^{79}$ In the GBE context, agency problems are magnified because there is not only an agency relationship between the government owner and the GBE's board, but the government itself is acting as the agent of the GBE's true owners, the public at large. This double agency scenario must be kept in mind when assessing the adequacy of the legal restraints on the conduct of the board. ${ }^{80} \mathrm{~A}$ lack of sufficient accountability mechanisms may allow GBE managers to place their own interests ahead of the interests of the public.

In the case of companies, the role of boards of directors is defined by s 198A of the Corporations Act, which provides that companies are managed by, or under the direction of, the directors. ${ }^{81}$ In companies with more than one director, the directors as a group form the board of directors. The distributor-retailers are not companies even if they meet the definition of 'corporation' under the Corporations Act. Accordingly, s 198A does not apply to the distributor-retailers. Instead, we must turn to the 2009 Act, which established the framework for the distributor-retailers' governance structure, starting with the creation of 'boards' (not 'boards of directors') comprised of 'members' or 'board members' (not 'directors'). ${ }^{82}$ Significantly, the governance structure applicable to distributor-retailers was changed in 2012 in the same legislation providing for Allconnex's disestablishment. ${ }^{83}$ The bulk of Section V will discuss the governance structure in effect up until the time of the 2012 Amendments. Subsection E.2 below discusses the changes made in 2012.

79 See generally Farrar, above n 40, 464-65.

80 See Victoria Schnure Baumfield, 'Restoring a Public Focus to Government Business Enterprises: Is a Fiduciary Duty to the Public the Answer?' (Paper Presented at Corporate Law Teachers Association Conference, Australian National University, 4 February 2013) $1-2$.

81 Corporations Act 2001 s 198A.

822009 Act ss 32-33; 2010 Regulations reg 4. Accordingly, in this article, 'director' means a company director, whereas 'board member' means a member of a distributor-retailer's board.

83 See South-East Queensland Water (Distribution and Retail Restructuring) and Other Legislation Amendment Act 2012 (Qld) (the '2012 Amendments'). 
The 2009 Act includes no direct analogue to s 198A, but s 32 of the 2009 Act (entitled 'Role of boards') provides detailed guidance about how the board is expected to operate. According to s 32(1), Allconnex's board was 'responsible for the way the distributor-retailer performs its functions and exercises its power.' The foregoing entailed 'deciding the [distributor-retailer's] strategies and the operational, administrative and financial policies'; 'ensuring the distributor-retailer performs its functions and exercises its powers in a proper, effective, and efficient way'; and ensuring that the distributor-retailer complies with its planning and reporting requirements. ${ }^{84}$ Accordingly, matters such as Allconnex's pricing policy were ultimately the responsibility of its board.

Public company boards normally consist of a mix of executive and non-executive directors. Executive directors are usually senior executives who work for the company full-time and are accordingly extremely knowledgeable about the company's day-to-day operations. Non-executive directors are not employed fulltime by the corporation and, ideally, bring an objective, outside perspective to the board's deliberations. Non-executive directors are often expected to be independent, meaning that they have no strong ties to the company such as a close familial or ongoing professional relationship. ${ }^{85}$ Modern corporate governance principles suggest that the majority of the directors on public company boards should be independent, including the chair. ${ }^{86}$

In Allconnex's case, the 2009 Act forbade members of the Queensland Water Commission, elected members of the participating councils, 'public service employees' (undefined), or board members of other distributor-retailers or other water entities from serving on Allconnex's board. ${ }^{87}$ In addition, at least three board members could not be 'associated employees', defined as an employee of a participating local government, and not more than two members could be associated employees. ${ }^{88}$ Furthermore, a person's ability to 'bring an independent judgment to

842009 Act s 32(2).

85 For useful guidance on whether a director qualifies as 'independent', see the ASX Corporate Governance Principles and Recommendations with 2010 Amendments ('ASX Corporate Governance Principles') 16-17.

86 Ibid 16-18.

872009 Act s 33(3).

88 Ibid s 33(4)-(5), Dictionary. This meant that in cases of distributor-retailers with at least three participants, not all of the participants could place a representative on the board (such as a council's CEO) simultaneously. In addition, the board was to consist of 'at least 3 members': s 33(1). But under the rules governing associated employees, there would need to be at least five members if two associated employees were named to the board. 


\section{THE ALLCONNEX WATER DEBACLE}

bear on the board's decision-making' was listed among the 'criteria for appointment' ${ }^{89}$ We can therefore conclude that Allconnex's board was expected to be filled mainly by the equivalent of non-executive directors exercising the same function as normally expected of a person in that role. The Participation Agreement in fact strengthened this requirement by requiring the board to be comprised of 'five non-executive Board Members, including a chairperson'. ${ }^{90}$ In other words, the Participation Agreement required the board to be composed entirely of the equivalent of non-executive directors.

The Corporations Act rules governing the appointment and removal of directors do not apply to the distributor-retailers despite their meeting the definition of 'corporation' since those rules apply only to companies. ${ }^{91}$ However, the Corporations Act director disqualification provisions (Pt 2D.6) do appear to apply to the distributor-retailers since those provisions refer to disqualification from managing corporations, not companies. Accordingly, not only would someone who has been disqualified appear ineligible to be named to the board of a distributor-retailer, but distributor-retailer board members who contravene a civil penalty provision of the Corporations Act (including by breaching their general duties to the distributorretailer under ss $180-183$ of the Act) may thereby be disqualified from managing corporations under s 206C of the Corporations Act.

\section{B Potential Portfolio Minister or Council Liability as Shadow Officers}

The Corporations Act's definition of director specifically contemplates that persons who were not properly appointed as directors may be considered directors of a company or other body for the purposes of the Act and subject to liability as though they were a properly appointed director. ${ }^{92}$ Depending on how these people come to

$89 \quad$ Ibid s 34.

90 See Participation Agreement $6 \mathrm{cl}$ 5.1. The difference in wording between the phrase 'associated employee', used in the 2009 Act, and 'non-executive Board Member', as used in the Participation Agreement, does not seem to have any substantive effect. Despite the requirements discussed above, it bears mention that Allconnex's initial board was comprised solely of associated employees (the chief executive officers of the three participating councils), although it later moved to all non-executive members, as required by its Participation Agreement: see Allconnex Water, 'Annual Report 2009-10' (30 September 2010) 5, 7, 27.

91 See Corporations Act Pt 2D3.

92 Corporations Act s 9 defines 'body' as 'a body corporate or an unincorporated body and includes, for example, a society or association' (emphasis added). Accordingly, a distributor-retailer appears to meet s 9's definition of 'body'. See s 9 (definition of 'director' sub-s (b)). 
act as directors, they may be what have been called de facto directors (s 9(b)(i) - a person who, while not properly appointed as a director, acts in the position of a director) or shadow directors (s 9(b)(ii) - the directors are accustomed to acting in accordance with the person's instructions or wishes even though the person was not validly appointed as a director). De facto directors include people who think that they are board members even though they technically are not due to some defect (eg, where a director's term expires without anyone noticing). ${ }^{93}$ Shadow directors are people who exercise a controlling influence over the board of directors although they are not themselves appointed as a director. ${ }^{94}$ The Corporations Act provides a safe harbour for professional advisers and others who are providing advice in the proper performance of functions attaching to the person's professional capacity or business relationship with the directors or the company. ${ }^{95}$ Those people will not be considered shadow directors. Although a company cannot be formally appointed as a director, a company may be held liable as a shadow director. ${ }^{96}$ This would typically occur where a parent company was directing the conduct of a subsidiary. ${ }^{97}$

Where GBEs are constituted as government owned corporations, the foregoing raises the possibility that the portfolio minister who gives directions to a board could be held liable as a shadow director. ${ }^{98}$ In Queensland, the Government Owned Corporations Act 1993 (Qld) ('GOC Act') negates any such possibility by specifically providing that 'a GOC's shareholding Ministers are not to be treated as directors of the GOC or any subsidiary. ${ }^{\prime 99}$ Furthermore, such a minister 'does not incur civil liability for an act or omission done or omitted to be done honestly and without negligence' with regard to the GOC. 100

The distributor-retailers' situation is not so clear. If, as this article suggests, they are corporations for purposes of the Corporations Act, then relevant persons may face liability as directors under the Corporations Act if they meet the requirements to be

\footnotetext{
93 Corporate Affairs Commission v Drysdale (1978) 141 CLR 236.

94 Re Hydrodam (Corby) Ltd [1994] 2 BCLC 180; Ho v Akai Pty Ltd [2006] FCAFC 159; ASC v AS Nominees Ltd (1995) 62 FCR 504.

95 Corporations Act s 9 (definition of 'director').

$96 \quad$ Standard Chartered Bank of Australia Ltd v Antico (1995) 38 NSWLR 290.

$97 \quad$ Ibid.

98 GOCs are subject to the Corporations Act unless specifically excepted by statute: Government Owned Corporations Act 1993 (Qld) s 76.

$99 \quad$ Ibid s 83(1).

100 Ibid s 83(2). To the extent that that minister would have incurred liability but for s 83(2), the State is liable instead: s 83(3).
} 


\section{THE ALLCONNEX WATER DEBACLE}

considered a de facto or shadow director as discussed above. Such persons might include, for example, members of the government to whom the board deferred.

Even if the Corporations Act does not apply, relevant persons may still face liability under the 2010 Regulations, which were defined in Section II.B above. Unlike the Corporations Act's definition of 'director', which distinguishes between properly appointed directors and others, the 2010 Regulations define 'board member' as simply (and circularly) 'a member of the board of the distributor-retailer' ${ }^{101}$ Presumably this definition relates solely to properly appointed members of the board. We can deduce that this must be the case because reg 4 of the 2010 Regulations defines 'officer' as not only (a) 'a person who actually holds appointment as an officer of the distributorretailer' but also (b) 'anyone else who (i) makes, or participates in making, decisions that affect the whole, or a substantial part, of the business of the distributor-retailer; or (ii) has the capacity to affect significantly the distributor-retailer's financial standing'. ${ }^{102}$ In other words, while the 'board member' definition does not include a 'shadow board member' concept, the 2010 Regulations' 'officer' definition does envisage the possibility of 'shadow' officers, particularly as sub-reg (b) of the 'officer' definition is specifically directed at people who do not actually hold appointment as an officer of the distributor-retailer. The people who could be picked up by sub-reg (b)(i) include the portfolio minister, participating councils, or even individual councillors to the extent that they actually had a say in a major decision before the board. ${ }^{103}$ Unlike in the Corporations Act, there is no safe harbour for advice properly given in the course of one's professional or business relationship with the distributor-retailer, if that advice is construed as participating in or making a decision affecting a substantial part of the distributor-retailer's business. Nor, unlike the GOC Act, is there a clause

\footnotetext{
1012010 Regulations reg 4.

102 Ibid (emphasis added).

103 In the case of the city councils, this might occur if they were to exercise their reserve powers as provided by ss 49 or 49A of the 2009 Act or the equivalent sections of the 2012 Amendments (see sub-s E.2 below) and, in Allconnex's case, cl 9 of the Participation Agreement. Significantly, s 51 of the 2009 Act indicates that regard must be had to any such direction when deciding whether a board member has satisfied his or her duty of care and diligence. This language suggests that where a board member has merely complied with an instruction given under the local governments' reserve powers (keeping in mind that s 49(3) of the 2009 Act states that 'the board must ensure the direction is complied with'), liability for negligent decisions would be bumped back from the board member to the local council(s) that gave the instruction. The only apparent way to do this, from a technical standpoint, would be by defining councils as officers as described here and hence making them subject to statutory duties to the distributorretailers under the 2010 Regulations or the Corporations Act.
} 
exempting the portfolio minister, participating councils, or anybody else from liability as a director or officer. If there is a possibility that the participating councils and portfolio minister may face liability for their involvement in a significant decision affecting a distributor-retailer, ${ }^{104}$ then that could chill those parties from taking adequate steps to rein in the distributor-retailers' boards where desirable. This would effectively nullify some of the most significant accountability mechanisms built into the distributor-retailer structure.

Nor has this problem gone away with Allconnex's dissolution. As the other distributor-retailers still exist, Parliament should cause the 2010 Regulations to be amended to make clear that neither the portfolio minister, the participating councils, nor anyone else acting on behalf of the participating councils is to be treated as an officer or director of the distributor-retailers for purposes of either the 2010 Regulations or the Corporations Act. At a minimum, Parliament should be aware that there is a discrepancy between how this issue is handled under the GOC Act and in relation to the distributor-retailers.

\section{Directors' and Board Members' Duties Compared}

Directors' and officers' general statutory duties are found in Part 2D.1 of the Corporations Act. These include the duty of care and diligence (s 180), the duties to act in good faith and for a proper purpose (s 181), the duty not to misuse position (s 182) and the duty not to misuse information (s 183). Section 184 makes certain breaches of ss 181-183 a criminal offence. Another significant obligation on company directors arises from the duty to prevent insolvent trading (s 588G). Sections 180-184 refer to directors of corporations - not companies - and hence apply to the distributorretailers' board members and officers (and, in the case of ss 182 and 183, employees) to the extent that the distributor-retailers are corporations for purposes of the Corporations Act. ${ }^{105}$ Section 588G, however, only applies to company directors (not directors of all corporations), and hence is not applicable to a distributor-retailer even if that entity is a corporation for Corporations Act purposes.

In addition, the 2010 Regulations provide that distributor-retailers' board members and officers owe duties that largely replicate the Corporations Act, 106 as follows:

104 The councils could theoretically face shadow liability under the theory set forth in Standard Chartered Bank of Australia Ltd v Antico (1995) 38 NSWLR 290.

105 See Section II.B above.

106 If a court were to find that the Corporations Act applied to the distributor-retailers, that would not prevent the 2010 Regulations from simultaneously applying to them: Corporations Act s 185. 


\begin{tabular}{|l|l|}
\hline $\begin{array}{l}\text { General Statutory Duties Under the } \\
\text { Corporations Act (plus s 588G) }\end{array}$ & $\begin{array}{l}\text { Analogous Provision of the 2010 } \\
\text { Regulations Applicable to Allconnex }\end{array}$ \\
\hline Section 180 - care and diligence & $\begin{array}{l}\text { Regulation } 6 \text { - but with additional } \\
\text { clarification of factors relevant to care } \\
\text { required (discussed below) }\end{array}$ \\
\hline $\begin{array}{l}\text { Section } 181 \text { - good faith and proper } \\
\text { purpose }\end{array}$ & Regulation 7 \\
\hline $\begin{array}{l}\text { Section } 182 \text { - misuse of position (applies } \\
\text { to employees as well as directors and } \\
\text { officers) }\end{array}$ & $\begin{array}{l}\text { Regulation } 8 \text { - but applies only to board } \\
\text { members and officers, not employees }\end{array}$ \\
\hline $\begin{array}{l}\text { Section } 183 \text { - misuse of information } \\
\text { applies to employees as well as directors } \\
\text { and officers) }\end{array}$ & $\begin{array}{l}\text { Regulation } 9 \text { - but applies only to board } \\
\text { members and officers, not employees }\end{array}$ \\
\hline $\begin{array}{l}\text { Section } 184-\text { criminalises certain breaches } \\
\text { of ss 181, 182, and 183 }\end{array}$ & Regulation 10 \\
\hline Section 588G - insolvent trading & No analogue \\
\hline
\end{tabular}

As the above table illustrates, the duties imposed on the distributor-retailers' board members under the 2010 Regulations for the most part substantively match those imposed under the Corporations Act. Other than the more restricted scope of regs 8 and 9 of the 2010 Regulations as compared to ss 182 and 183 of the Corporations Act, the only real substantive difference is found in reg 6, which imposes a duty of care and diligence on board members and officers of the distributor-retailers.

Regulation 6 of the 2010 Regulations picks up the entirety of s 180 of the Corporations Act, including the business judgment rule found at s 180(2). In addition, reg 6(2) lists factors to be considered in deciding the degree of care and diligence required: the distributor-retailer's geographic area functions as set forth in s 11 of the 2009 Act; ${ }^{107}$ its other functions under the 2009 Act and other acts; requirements imposed by the distributor-retailer's participation agreement; and any directions received by the participating local governments. The inclusion of the last factor reinforces the possibility that board members may not be liable for breaches of the duty of care where they have simply carried out a local government direction, particularly since s 51 of the 2009 Act also says that in deciding whether a board member has exercised an appropriate degree of care and diligence, regard must be had to any relevant local

107 Section 11 of the 2009 Act defines the distributor-retailers' geographic area functions to include: purchasing water from the water grid manager; distributing water; providing water and wastewater services; charging customers for relevant services; managing customer enquiries, service requests and complaints; etc. 
government direction. This further supports the possibility that liability in such cases would be pushed back onto the relevant local governments, perhaps under a form of shadow officer liability.

Despite the additional verbiage, reg 6(2) does not substantially change the duty of care from that owed under the Corporations Act. Regulation 6, like s 180, makes clear that there is both an objective, reasonable person, standard to the duty of care, and a subjective standard based on both the distributor-retailer's circumstances and the responsibilities and position held by the relevant board member. The new language relates to the first of those subjective factors - the distributor-retailer's circumstances. Since reg 6(2) merely lists circumstances that would exist in any event, presumably they would already be raised by any competent lawyer to the extent relevant. At most, this additional text does no more than clarify which factors must be taken into account. 108

As previously mentioned, the Corporations Act requires company directors (ie, not the distributor-retailers' board members, since the distributor-retailers are not companies) to prevent their company from incurring a debt when insolvent, or where the debt would cause the company to become insolvent. ${ }^{109}$ No similar provision appears in the 2010 Regulations or 2009 Act.

The foregoing considered statutory duties. What about the general law duties imposed on company directors, ${ }^{110}$ which in some cases differ slightly from or expand upon the statutory duties set forth in the Corporations Act? Section 185 of the Corporations Act states that ss 180 to 184 'have effect in addition to, and not in derogation of, any rule of law relating to the duty or liability of a person because of their office or employment in relation to a corporation.' This language has been held to mean that ' $[t]$ he statutory duties of a director are in addition to, not in derogation of, a director's duties under the general law.' 111 Accordingly, assuming the distributor-retailers meet the definition of 'corporation', then their board members

108 Other relevant factors under s 180 include whether the entity was facing rapidly deteriorating financial circumstances (see, eg, ASIC $v$ Rich [2003] NSWSC 85); whether it was a large company 'with a large annual turnover, large stake in assets and liabilities, ... and hundreds, if not thousands of employees' (AWA Ltd v Daniels (1992) 7 ACSR 759, 864); and the nature of the company's business or the transaction contemplated, keeping in mind that a risky business or transaction might need more diligent oversight than a stable or routine one (eg, Permanent Building Society (in liq) v Wheeler (1994) 14 ACSR 109).

109 Corporations Act s 588G.

110 For example, the duty to avoid conflicts of interests, the duty not to fetter discretion, etc.

111 Swansson v Pratt [2002] NSWSC 583, [72]. 


\section{THE ALLCONNEX WATER DEBACLE}

clearly are also subject to the general law on directors' duties, encompassing such areas as the general law duty to avoid conflicts of interest.

With regard to conflicts, under the general law the duty will be breached unless the director makes full and frank disclosure of the conflict to the company and receives the company's consent. ${ }^{112}$ Company directors are also required by s 191 et seq of the Corporations Act to disclose any material personal interests in matters affecting the company's affairs to the board of directors (as opposed to the company in general meeting, as required under the general law) and, in the case of public company directors, to generally abstain from participating in discussions of the merits of or voting on the matter. An interesting divergence in the rules governing company directors and distributor-retailers' board members could have theoretically arisen here, since the statutory conflict rules (ie, s 191 et seq) apply only to company directors as opposed to the directors of other sorts of corporations. However, s 42 of the 2009 Act made similar provisions applicable to distributor-retailers' board members. Accordingly, the substance of the statutory conflicts rules would apply even if the distributor-retailers were not subject to the general law on conflicts.

In this vein, it appears that the distributor-retailers are likely subject to the general law directors' duties even if they are not corporations and hence not bound directly by s 185 of the Corporations Act. That is because reg 11 of the 2010 Regulations adopts s 185 essentially verbatim, with the only change being a substitution of the word 'distributor-retailer' for the word 'corporation'. Although reg 11 could have been clearer (for example, by specifically referencing the general law duties applicable to company directors), reg 11 presumably was intended to pick up the general law directors' duties and make them applicable to the distributor-retailers' board members just as regs 6-10 did with regard to directors' statutory duties. This makes sense since the thrust of the 2010 Regulations is that board members are to comport themselves like directors, and it is unclear what other pre-existing general law duty would apply.

Furthermore, the Queensland government itself acknowledges that 'as Government Board members will often be in an [sic] similar position to a company director, they may be subject to fiduciary obligations' under the general law. ${ }^{113}$ The Queensland

112 See, eg, Regal (Hastings) Ltd v Gulliver [1967] 2 AC 134; Furs Ltd v Tomkies (1936) 54 CLR 583. This traditionally means disclosure to the shareholders, who must vote to approve the conflict in a general meeting. In the distributor-retailers' case, presumably the general law would require disclosure to and the consent of a majority of the participating councils even though the councils technically are not 'members' and do not hold general meetings as such.

113 Queensland Department of the Premier and Cabinet, above n 33, 11-13. 
government therefore informs new board members that '[c]ompany directors, and other Government Board members acting in a fiduciary capacity', have an obligation to act honestly and to exercise powers for their proper purposes; avoid conflicts of interest; act in good faith; and exercise diligence, care and skill. ${ }^{114}$

Board members also are subject to reg 12 of the 2010 Regulations, which imposes a 'duty of confidentiality to the distributor-retailer to the same extent as if the distributor-retailer was a company registered under the Corporations Act and the board member was a director of the company.' Regulation 12, to this author at least, is a mystery. No similar provision regarding a general 'duty of confidentiality' (as opposed to s 183's prohibition on the misuse of confidential information) appears in the Corporations Act, and even the confidentiality duty that directors owe at general law is usually characterised as a duty not to misuse confidential information (like s 183) rather than a general 'duty of confidentiality' as such. ${ }^{115}$ But reg 9 of the 2010 Regulations already applies s 183 to the distributor-retailers. There are, of course, common law duties of confidentiality not specific to company directors that also may apply if their elements have been met. But reg 12 does not appear to be referring to those duties since it imposes a 'duty of confidentiality' only to the extent that one exists with regard to companies. Accordingly, it is unclear what additional purpose reg 12 is intended to serve.

The final point of comparison concerns delegation and reliance. Company directors may delegate any of their powers in the circumstances provided for by s 198D of the Corporations Act, and directors may have a defence to claims of breach of duty when they have delegated their powers if s 190's requirements are met.116 Sections 190 and 198D apply specifically to companies, not to all corporations. Accordingly, these provisions will not apply to the distributor-retailers even if they, as corporations, are subject to the Corporations Act.

Directors may have a reliance defence where they properly relied on information or advice given or prepared by employees, other directors, or professional advisers in accordance with s 189 of the Corporations Act. This provision is applicable to corporations in general, not just to companies, and hence will apply to the distributor-retailers to the extent that those entities meet the definition of corporation.

Regulation 13 of the 2010 Regulations adopts a reliance defence similar to s 189, and s 53(3) of the 2009 Act provides that the board may delegate any of its functions. But,

\footnotetext{
$114 \quad$ Ibid 11.

115 See, eg, Pacifica Shipping Co Ltd v Anderson [1986] 2 NZLR 328; Faccenda Chicken Ltd v Fowler [1987] 1 Ch 117.

116 Corporations Act s 190.
} 
unlike the broad power to delegate provided by s 198D, ${ }^{117}$ a distributor-retailer's board may delegate only to a board committee or the distributor-retailer's CEO.118 Furthermore, the 2010 Regulations include no delegation defence analogous to s 190 of the Corporations Act. The clear message for board members is to closely supervise any delegation of their powers since they may be liable even where the delegate seemed competent and reliable.

\section{To Whom Are Duties Owed - Ensuring that Council and Ratepayer Concerns Are Taken into Account}

Directors' duties are owed to the company. In the case of a solvent company, 'the company' normally means the shareholders as a whole. ${ }^{119}$ Duties are not normally separately owed, for example, to a majority shareholder even though the majority shareholder might be disproportionately harmed by any breaches of duty due to its large shareholding. The system works because the interests of the shareholders en masse normally coincide with the interests of the majority shareholder.

The 2010 Regulations, similarly, state that the board members owe their duties to 'the distributor-retailer'. ${ }^{120}$ Under the orthodox view, this would mean that the board members do not owe duties to the individual participating councils, much less the councils' constituents, even though the councils are ultimately no more than a standin for their residents, who generally have no say in their dealings with the distributor-retailers, either as customer or as conceptual ultimate owner. This is the case even though the convergence of interest that we would normally see between shareholders and 'the company' would not necessarily obtain in the distributorretailer context. For example, even though the participating councils would potentially benefit in the form of higher dividends if a distributor-retailer charged more for its services, the councils might prefer that it charge less and keep ratepayers happy. ${ }^{121}$ Accordingly, the rules here should be tailored to accommodate the unique

117 Ibid s 198D allows for delegation to board committees, a director, a company employee, or any other person.

1182010 Regulations reg 53(3).

119 See, eg, Percival v Wright [1902] 2 Ch 421 (directors and officers owe duties to 'the company as a whole', not to any individual shareholder); Greenhalgh $v$ Arderne Cinemas Ltd [1951] Ch 286, 286 ("[The phrase] "[t]he company as a whole", does not ... mean the company as a commercial entity as distinct from the corporators. It means the corporators as a general body.').

$120 \quad 2010$ Regulations reg 7.

121 Conversely, perhaps councils might be happy for the distributor-retailer to charge as much as it could get away with since profits are remitted to the councils as dividends - 
nature of council ownership. The next few paragraphs discuss how this can be accomplished.

Under the general law, there are exceptional cases where directors have been held to owe duties to one or more shareholders. ${ }^{122}$ The duty arises in contexts where the directors' conduct personally affects those shareholders. For example, the duty has been held to exist: when a director is seeking to personally buy shares from a shareholder; when directors solicit shareholders to make a further investment in the company; when directors ask shareholders to adopt a resolution in general meeting; and when takeover negotiations are underway. ${ }^{123}$ In these cases the duty is typically a 'limited' duty to take steps 'to negate the effect, in the particular circumstances, of his taking advantage in an unconscionable way of the superior position occupied by [the director].' ${ }^{124}$ This limited duty to shareholders does not negate the 'comprehensive fiduciary duties' that directors owe to the company. ${ }^{125}$

In the case of the distributor-retailers, the board members should owe an analogous duty to their individual shareholders. The scenarios where this duty has been held to exist are ones where shareholders are vulnerable to the directors and dependent upon them to provide full information or otherwise make sure that the shareholders' interests are adequately protected. The councils are similarly vulnerable. The vulnerability arises from the fact that the participating councils, much like their constituents, have no choice but to deal with the distributor-retailer. The councils are forced to be shareholders; they cannot (currently, at least) sell out. At the same time, as discussed in sub-s E.1 below, the councils had (at least until the 2012 Amendments revised the law) only a very limited ability to veto board decisions. Even now, councils presumably will not veto board decisions lightly. So board members will often face no real consequences if the councils are unhappy. This surely must colour their thinking when considering feedback from the councils. For example, this seems to be the dynamic that was in play between Allconnex and the GCCC. The councils are also vulnerable because the councils to a certain extent face the consequences if their constituents (the distributor-retailers' customers) are unhappy with the

money that could ease budgetary squeezes, relieving pressure on the councils to raise rates.

See, eg, Brunninghausen v Glavanics (1999) 46 NSWLR 538; Coleman v Myers [1977] 2 NZLR 225.

See John Gooley et al, Corporations and Associations Law: Principles and Issues (LexisNexis Butterworths, $5^{\text {th }}$ ed, 2011) 627-630 (providing detailed listing of scenarios where a duty to shareholders arises).

Ibid. 
distributor-retailers. Constituents complain and expect the councils to respond. Anger towards the distributor-retailers even has the potential to affect elections. Normally, unhappy customers would not complain directly to a company's shareholders or expect them to fix the problem. Based on the abnormal impact that the boards' conduct can have on their shareholders, it is appropriate to require boards to have regard to the impact of their decisions on their participating councils. To avoid confusion as to the existence and scope of the duty, the duty should be written into the 2010 Regulations.

The unique nature of the relationship between the distributor-retailers and their owners further supports the argument that duties should be owed to the participating councils. First, the number of shareholders is in each case extremely small. For example, Allconnex had only three shareholders - the three local government participants. This is not a situation where the shareholders were voluminous and the directors had no real relationship with many or most of them. To the contrary, Allconnex's board members not only knew exactly who the three shareholders were but what their concerns were. ${ }^{126}$ The situation is similar to a small proprietary company where shareholders often have more involvement in management than in a larger company - and where in many cases this increased involvement is formalised by the adoption of appropriate provisions in the company's constitution. Creating the enhanced duty proposed here would do no more than place the distributor-retailers' shareholders on a similar footing to the situation enjoyed by many other shareholders of closely-held concerns.

Nor, following the public trust theory, should the distributor-retailers' public status and indeed public purpose be forgotten. Distributor-retailers should be managed for the benefit of the public (including their customers) and the law should reflect this. The easiest way to do so would be by creating a statutory duty. The duty would have to be more specific than something simply requiring the distributor-retailers to act in accordance with the public's concerns, however, because a duty so phrased would be too vague or ambiguous to be enforced. Moreover, it would potentially create a conflict with other legal obligations, such as the requirement to break even or make a profit.

A more feasible first step would be to adopt a provision akin to s 172 of the UK Companies Act 2006, which imposes a duty to 'promote the success of the company.' Under s 172, UK company directors must 'have regard to' various stakeholders and

126 Indeed, Allconnex's interim board, which managed the company until April 2010, was comprised of the CEOs of the 3 participating councils. See Allconnex Water 2009-10 Annual Report, above n 90, 5, 7, 27. 
concerns when performing their duties. ${ }^{127}$ Section 172 was intended to force UK companies to consider corporate social responsibility ('CSR') principles as part of their decision-making processes. It is not a panacea, as it does not mandate companies to act in a more socially responsible way, but it is a start.

The extent to which adherence to CSR principles should be required as opposed to merely encouraged (or tolerated, depending upon one's point of view) is still under debate in Australia. The adoption of a rule like s 172 would be controversial if applied to ordinary trading corporations because of concerns such as that s 172 unacceptably diffuses accountability to a corporation's shareholders and muddies corporate objectives from the previously clear goal of profit maximisation. In the case of the distributor-retailers, however, muddying corporate objectives away from profit maximisation might actually be a benefit.

It is ironic that GBEs such as Allconnex are seemingly being discouraged from considering the needs and concerns of the public at the same time that private sector businesses are increasingly expected to be managed in ways consistent with the precepts of good CSR to differentiate themselves, gain or retain the goodwill of their customers and communities, and minimise legal risk. Clearly public authorities like the distributor-retailers, which by definition should be concerned with the public weal and in fact are often obligated already to consider public concerns through mandated community service obligations ('CSOs'), as discussed further in Section VI below, should be required to consider CSR principles in their decision-making.

Here, a s 172-like provision inserted either into the 2010 Regulations or, more ambitiously, into a statute applicable to all GBEs could require board members to gather information about and have regard to the concerns of the participating councils and their constituents (ie, the distributor-retailers' monopoly customers and conceptual ultimate owners ${ }^{128}$ ). The requirement could also be extended to cover the broader community of stakeholders, including employees, suppliers, the general community, and the environment, but this point is of secondary importance. Since

127 Companies Act 2006 (UK) s 172 creates a new duty upon directors to act in ways 'most likely to promote the success of the company for the benefit of its members as a whole.' Directors are specifically instructed to have regard to: the likely long-term consequences of decisions; the interests of employees; the need to foster business relationships with suppliers, customers, and others; the impact of the company's operations on the community and environment; the desirability of the company maintaining a reputation for high standards of business conduct; and the need to act fairly as between members of the company.

128 Hughes Aircraft Systems International v Airservices Australia (1997) 76 FCR 151, 196; Whincop, above n 39, 7-8. 


\section{THE ALLCONNEX WATER DEBACLE}

GBEs are agents of the government, it is most critical that the law recognise and place value on the needs and concerns of the government owners and the constituents they represent.

It is true that such a rule would not mandate a particular outcome, but even requiring the board to go through the process of formally considering how their decisions would affect the relevant stakeholders might cause the final decision to be more in harmony with the public's concerns. Keeping in mind that the entities upon which this obligation would be imposed are an extension of the government, it is hard to justify not requiring them to consider the impact of their decisions upon the community and take into account community views. Furthermore, adding a requirement to consider the position of these parties during the decision-making process would be, in reality, quite a modest change to existing law. Perhaps the hardest part of the process from the GBE's perspective would be ascertaining that it had gathered enough information to satisfy the law's information-gathering requirement. This concern could be dealt with by setting minimum standards (eg, a GBE must solicit public comment regarding a relevant decision on its website for at least 30 days) in either the Statute itself or corresponding regulations.

Why are CSOs, on their own, insufficient to ensure the public's needs are taken into account? As discussed in Section VI below, CSOs tend to be directions to perform very specific activities that are not in the GBE's commercial interests, in return for compensation for losses incurred in complying with the CSO. CSOs may certainly have prevented some disputes between GBEs and the public from arising. But there may well be unanticipated cases - as occurred with Allconnex - where there is no CSO on point. Even if a CSO could eventually be imposed after a dispute arises, what happens in the interim? A broader duty to have regard to the public's concerns would help fill that gap. Another option would be to shift to broader CSOs than we usually see. It is not clear that this would be feasible, particularly in light of the compensation requirement usually attached to CSOs. It may be better to retreat from the current expectation that GBEs, monopolies in particular, should be run like private sector businesses and expected to make a profit - then compensation would not be so critical. In any event, broader CSOs might functionally be little different than the duty proposed here anyway, just under another name.

In response to concerns that creating a duty to GBE stakeholders would open the floodgates to a tsunami of harassing litigation, relatively restrictive standing rules such as apply in other types of public interest litigation could limit standing on behalf of 'the public' to, for example, legitimate public interest groups. Alternatively, leave of court could be required to commence proceedings, similar to the process 
required before a statutory derivative action can be commenced by a shareholder on behalf of a company. ${ }^{129}$

This is not to ignore that the distributor-retailers' boards have a legal obligation to achieve the objectives set out in their governing documents, which objectives may conflict with what their participating councils (or those councils' constituents) desire. In such cases, it is only natural that board members will prefer to satisfy their legal obligations. The answer is not to conclude that shareholders' concerns should be ignored in such circumstances but, again, to revise the distributor-retailers' legal obligations. This would at least provide an effective counterweight to the current emphasis on commercial considerations. In this regard, we should recall that Allconnex's CEO justified the price increases with the claim that the obligation to 'optimise returns' to the councils left him with no choice but to charge as much as possible. ${ }^{130}$ Creating such a duty would have given him legal cover to charge less.

\section{E Accountable to Multiple Masters or to None?}

A more fundamental question is to whom, ultimately, are the board members responsible or accountable? In other words, who, practically speaking, can influence how they wield their power? In private sector companies that person is typically the majority shareholder (if one exists) since that person has the power to remove the board if unhappy with the directors' performance. In a typical GBE (including GOCs), a similar situation exists, since the majority (indeed, sole) shareholder is usually the portfolio minister, to whom the GBE's board will normally be required to report in any event. The situation is not quite so clear in the case of the distributorretailers. Accountability is split among the participating councils, the portfolio minister, and, in some cases, effectively nobody at all.

In some important respects Allconnex's participating councils did have real power over Allconnex's board, starting with the fact that the councils, not the State-level portfolio minister, had control over who was appointed to the board. ${ }^{131}$ Until passage of the 2012 Amendments, however, board appointments could only be made by the Required Majority. ${ }^{132}$ This limited the power of individual councils to name at least

129

See Corporations Act ss 236-37.

See Allconnex Water, 'A Statement by Allconnex Chairman John Dempsey' (Media Release, 29 March 2011)('The [participation] agreement clearly states that we are obliged to 'optimise the return on investment' to the [participating] councils ... Until those governing principles are changed, price increases of 12-15 percent are necessary.').

131 Participation Agreement $6 \mathrm{cl}$ 5.2. Furthermore, the (council-appointed) board, not the portfolio minister, is responsible for appointing the CEO: 2009 Act s 44.

Participation Agreement $6 \mathrm{cl}$ 5.2. The Required Majority concept is discussed below. 


\section{THE ALLCONNEX WATER DEBACLE}

one champion for their separate interests and is one way that the distributor-retailer governance structure, as originally created, neutered the power of the majority shareholder.

In addition, the 2009 Act and Participation Agreement required Allconnex to prepare a five year plan about its future direction, goals, and priorities. ${ }^{133}$ In the GOC context, Grantham observes that the corporate planning process allows the government to retain significant control over the company's direction and strategic goals. ${ }^{134}$ That is because the corporations' shareholding ministers, in both the Queensland and Commonwealth systems, ${ }^{135}$ have effective final control over the plan (known in those jurisdictions as the 'Statement of Corporate Intent'). ${ }^{136}$ In Allconnex's case, Allconnex was required to 'consult with the Participants in formulating and reviewing the Five Year Forward Plan'. ${ }^{137}$ This certainly would appear to give the participating councils some ability to influence the distributor-retailers' goals and priorities. But as long as Allconnex 'consult[ed] with' the councils, it satisfied its legal obligation. Unlike a GOC, Allconnex could hear what the councils had to say and then ignore them. So, while a consultation requirement is better than nothing, any power granted to Allconnex's owners through the planning process was ultimately illusory.

Furthermore, in connection with some matters, the person with ultimate power over the distributor-retailers is not their owners at all but the portfolio minister ${ }^{138}$ - an interesting form of separation of ownership and control. ${ }^{139}$ For example, if a distributor-retailer and participating councils had not agreed to a participation agreement by 30 April 2010, the portfolio minister had the power to impose one. ${ }^{140}$ In

Ibid $10 \mathrm{cl} 6.1 ; 2009$ Act s 21.

134 Grantham, above n 53, 182.

135 See GOC Act; Commonwealth Authorities and Companies Act 1997 (Cth).

Grantham, above n 53, 184; see also GOC Act ss 97-98, 107-08. In Queensland, for example, the GOC and shareholding ministers must agree to the corporate plan. If unable to do so shareholding ministers may direct the board to take specified steps with regards to the draft plan or make specified modifications to it. Participation Agreement $10 \mathrm{cl}$ 6.1(b)(i).

138 At the time period relevant to this article, Minister for Energy and Utilities Stephen Robertson.

Inherent to the corporate form is the separation of ownership and control that exists in all but the smallest companies. Normally, however, the people with control (the board) are ultimately answerable to the company's owners, particularly the majority owner if one exists, who can sack the board if unhappy with its behaviour. What is different here is that the board is ultimately answerable in connection with these matters to somebody other than the owners.

2009 Act s 23. 
addition, no participation agreement was effective until approved by the minister. ${ }^{141}$ Therefore, the portfolio minister had veto power over each participation agreement's contents. Furthermore, ministerial approval is required for certain critical changes to participation agreements, including as to:

- who may be a participant and who may cease to be one (foreshadowing any future privatisation attempts);

- who the participants are;

- changes in participation rights; and

- the participation agreement's planning and reporting requirements. ${ }^{142}$

In addition, the minister was empowered to make a customer water and wastewater code to provide for the rights and obligations of distributor-retailers and their customers. ${ }^{143}$ Finally, by statute the distributor-retailers' annual reports were to be directed to the portfolio minister, not their owners, the councils, ${ }^{144}$ although in Allconnex's case the Participation Agreement required that a copy also be provided to the council-owners. ${ }^{145}$

So councils have some ability to influence distributor-retailers' management decisions through nonbinding input into their strategic plans, along with reserve powers to give instructions to the board where in the public interest and the power to appoint the board. The portfolio minister has the final say over key aspects of the council/distributor-retailer relationship. The portfolio minister does not have input (at least not formally) into the substantive matters of distributor-retailer management left to the councils. ${ }^{146}$ Since the distributor-retailers are not required to heed the councils' wishes in that area, unless those wishes are expressed in the form of a binding direction, it means that in large part ultimately no one representing the public has a binding say in how the distributor-retailers run their businesses, despite their status as public authorities. This was ultimately what doomed Allconnex, in

\footnotetext{
$141 \quad$ Ibid s 24.

$142 \quad$ Ibid s 29.

143 Ibid ch 4.

$144 \quad$ Financial Accountability Act 2009 (Qld) s 63.

145 Participation Agreement $12 \mathrm{cl} 7.1$.

146 The extent to which political power allows the portfolio minister to influence the distributor-retailers' strategic plans despite having no formal right to be consulted as part of the planning process is unclear. But certainly the portfolio minister's ability to set overall policy in the water area must have some effect.
} 


\section{THE ALLCONNEX WATER DEBACLE}

combination with Allconnex management's apparent disregard for how its policies were being received by the public.

\section{Rules Regarding Required Majorities and Reserve Powers Neuter the Majority Shareholder}

Company directors normally pay attention to the wishes of, in particular, majority shareholders because otherwise they will be replaced. This is yet another area where, in Allconnex's case, the usual rules did not apply. The GCCC owned $61.65 \%$ of Allconnex's shares, known in this context as Participation Rights. ${ }^{147}$ Yet it had the power neither to appoint nor to remove a board member without the consent of at least one other participating council. Both appointment and removal of directors required action by the 'Required Majority'. ${ }^{148}$ A 'Required Majority' was defined as 'at least two of the three Participants who together hold more than $50 \%$ of the total Participation Rights' where the Participants' councils have each passed a resolution agreeing to the matter. ${ }^{149}$ Here, that meant the GCCC plus either Logan or Redlands City Council, despite the Gold Coast's 61.65\% ownership interest. (Logan and Redlands could not constitute a required majority without the Gold Coast since their combined shareholding totalled less than $50 \%$.) So even if it had wanted to (which is not clear), the Gold Coast could not replace Allconnex's board despite the GCCC owning well over half of Allconnex's shares. The other distributor-retailers' participation agreements also include the required majority concept. ${ }^{150}$

Unlike a company, whose shareholders generally may not interfere with management decisions, a distributor-retailer's shareholders do have 'reserve powers' to direct a distributor-retailer 'about the way [it] is to perform its functions.' ${ }^{151}$ Until 2012, the participants could do so by issuing a written 'local government direction' (now called a 'group direction'). ${ }^{152}$ These reserve powers may only be exercised where it is both 'necessary' and 'in the public interest' to do so. ${ }^{153}$ Again, however, before 2012, a majority shareholder could not exercise the shareholders' reserve powers on its own. Either a required majority or all of the local governments, depending on the particular participation agreement, had to agree to do so. ${ }^{154}$ In

\footnotetext{
147 See Participation Agreement dated 25 June 2011 incorporating Amendment No 2, 19 sch 1; Allconnex Water, 'Participation Agreement Summary as at March 2012', 2.

148 Participation Agreement 6-7 cls 5.2, 5.5.

149 Ibid 3.

150 See 2009 Act s 49(2)(a)(ii).

151 Ibid s 49. Government owners of GBEs typically possess reserve powers.

152 Ibid, former s 49 (pre-2012 Amendments).

153 Ibid s 49(2)(b)(i).

154 Ibid s 49(2)(a).
} 
Allconnex's case, the Participation Agreement required unanimity for such a direction to be issued. ${ }^{155}$ In other words, despite the GCCC owning a greater proportion of Allconnex than Allconnex's other two council-owners put together, Allconnex was structured as a tyranny of the minority in which the GCCC could take no action to direct Allconnex management how to perform its functions unless both of the minority councils agreed. ${ }^{156}$

\section{The 2012 Amendments Belatedly Strengthen Accountability to the Council Owners, Imposing Contradictions Requiring Legislative Amendment}

Although it did not act in time to prevent Allconnex's demise, the Queensland Parliament did eventually revise the 2009 Act - ironically, in the same legislation that provided for Allconnex's disestablishment. The changes indicate that the government, in its own post-mortem of what went wrong, must have focussed on the same problems as set forth above. The changes give more control to the remaining distributor-retailers' council-owners.

First, each participating council was given the right to place one councillor on its distributor-retailer's board. ${ }^{157}$ Previously this was not allowed. ${ }^{158}$ However, the new provisions simultaneously provide that 'a board can not have more than 3 councillormembers'. ${ }^{159}$ This creates a potential problem in Queensland Urban Utilities' ('QUU') case because it is owned by five participating councils. ${ }^{160}$ What happens if all five councils seek to exercise their right under new s 33(3) of the 2009 Act to place a councillor on QUU's board, when new s 33(4) limits the number of councillors on a

155 Participation Agreement $15 \mathrm{cl} 9$.

156 Of course, company law generally forbids shareholders from interfering with management decisions, too: see, eg, NRMA v Parker (1986) 4 ACLC 609. But if the board is not responsive to the desires of a majority shareholder, the majority shareholder normally will have the power to replace the board.

2012 Amendments s 12, new s 33(3) (providing for the newly defined 'councillormembers'). The new ss 33-36 set out in the 2012 Amendments replaced in their entirety the ss 33-36 previously included in the 2009 Act. Note that when a councillor-member 'is acting in the person's capacity as a councillor-member, the member's responsibilities as a councillor ... do not apply': 2012 Amendments s 19, new s 52A.

158 See Section V.A above.

1592012 Amendments s 12, new s 33(4).

160 Those councils are Brisbane City Council, Ipswich City Council, Lockyer Valley Regional Council, Scenic Rim Regional Council, and Somerset Regional Council: see Queensland Urban Utilities, above n 10. The other remaining distributor-retailer, Unitywater, has only two owners: Unitywater, see above n 9. Perhaps the drafters of the new s 33(4) had Allconnex in mind and forgot that one of the other distributor-retailers had more than three participants. 


\section{THE ALLCONNEX WATER DEBACLE}

board to three? Parliament should clarify how it intended these sections to work together, perhaps by providing for a system of rotating councillor-members, before it becomes a live issue.

In addition, new provisions were included that, it seems, intended to preserve the board's independence. But they only work if s 33(4) prevails over s 33(3) such that the board has no more than three councillor-members. Specifically, while the minimum number of board members was increased from three to five, ${ }^{161}$ the board was now required to have at least three 'independent members'. ${ }^{162}$ Therefore, board minimums would now be six if three councillor-members were named to the board, preventing the insiders (the councillor-members) from outnumbering the independent members. The fact that the chair must be independent means that the board could arguably be classified as independent under this scenario. ${ }^{163}$ If s 33(4) is revised to conform with s 33(3), for example by deleting the limit on the number of councillor-members but providing that a board can have no more than one councillor-member per participating local government, then to preserve board independence s 33(5) will need to be revised to say that there must be at least one independent member for each councillor-member. In that case, the minimum number of board members would be 10 in QUU's case - at which stage the board's size might start to become unwieldy. ${ }^{164}$ Alternatively, s 33(3) must be revised to remove the guarantee that all participating councils can have a councillor on the board simultaneously. But this option is not desirable if the goal is to give the council-owners more say in what the distributor-retailers are doing.

The other significant change relates to the participating governments' reserve powers. In addition to the participants' previous ability to give a 'local government direction' (re-named a 'group direction' in the 2012 Amendments) where all or a required majority of them (depending on their participation agreement) agreed, the 2012 Amendments introduced a new concept called 'individual directions' ${ }^{165}$ Now, any single council owner can issue a direction on how the distributor-retailer is to perform its function relating specifically to that council's local government area. ${ }^{166}$ Significantly, the matters about which individual directions may be given include:

\footnotetext{
1612012 Amendments s 12, new s 33(1).

162 Ibid s 12, new s 33(5). New s 36 lists the attributes that would disqualify one from being an independent member.

163 Independence of the chair is required by s 12, new s 36B.

164 On the other hand, QUU's board already has eight members, so a 10-member board perhaps would not make much difference.

1652012 Amendments s 16 (insertion of new s 49A).

166 Ibid.
} 
charges to connect customers to the distributor-retailer's water and wastewater services; charges for a customer's use of the services; and charges related to providing infrastructure for the services. ${ }^{167}$ In other words, the council cannot prevent the distributor-retailer from fully passing on the bulk water component of the final water price, as it is required to do, ${ }^{168}$ but the council can direct the distributor-retailer to decrease the spread between the wholesale and retail price charged for water. In return, the council must compensate the distributor-retailer for direct and foreseeable financial losses resulting from the direction. ${ }^{169}$ If the council and distributor-retailer cannot agree as to the amount of compensation due, they will be able to resort to default rules about calculating liability and dispute resolution to be established by regulation (presumably to be added to the 2010 Regulations). ${ }^{170}$

\section{$3 \quad$ Wherefore Accountability?}

This article's analysis presupposes that the distributor-retailers should be held accountable, but for what? Keeping water prices low? Covering all of their costs? Being forced to operate efficiently to keep water prices low?

Understanding what the public wants from these entities raises the possibility of a mismatch between the public's expectations and one of the theoretical or philosophical purposes of moving from a government-run to a government-owned business model. Much of the corporatisation trend is predicated on the expectation that GBEs will act like and be placed on a level playing field with other businesses. GBEs are increasingly expected to operate in accordance with the principles of competitive neutrality, including by removing subsidies, meaning they have to cover their own costs, so that eventually government businesses can be opened up to competition. The goal is to increase efficiency, leading to better service at lower cost to the customer. Corporatisation has also been attractive to policymakers because it allows for debt associated with the businesses to be removed from the government balance sheet.

But Allconnex remained a monopoly, and, despite the possibility that some areas of water services might be amenable to competition, perhaps at least some aspects of water delivery are indeed natural monopolies where competition will never be truly possible. For example, the notion of multiple water companies building competing water pipe networks in a given locale seems unlikely if it is even possible. In the case of the distributor-retailers, there has been no suggestion that they would be opened

\footnotetext{
167 Ibid.

168 See Section VI.A below, discussing the 1994 COAG Communiqué.

1692012 Amendments s 16, new s 49A(3)(d); s 70 (insertion of new s 99BZD).

170 Ibid s 70, new s 99BZD(4)-(6).
} 


\section{THE ALLCONNEX WATER DEBACLE}

up to competition anytime soon. ${ }^{171}$ So to the extent that Allconnex's business was expected to be run according to the principles of competitive neutrality, ${ }^{172}$ especially to the extent that doing so was viewed as justification for allowing water prices to rise precipitously, that expectation was based on the false premise that Allconnex should not have any competitive advantage (due to the existence of hidden government subsidies) over its competitors. The premise was clearly false since those competitors did not, and possibly never will, exist. That expectation also led to a result - dramatically higher water prices - that the public clearly was not willing to accept, especially when those prices were even further inflated by Allconnex's perceived need to maximise profits.

Perhaps we should prefer higher water prices anyway, to encourage water users to limit water consumption. But there is a limit to just how much more consumption (at the residential level, at least) can decline. ${ }^{173}$ And everyone needs water. So perhaps this was the crux of the problem: the owners of Allconnex wanted to keep their constituents happy by requiring Allconnex to keep prices low while the people setting water policy (the State government) perhaps wanted those same constituents to be unhappy to get them to change their behaviour. This is where holding an entity accountable to multiple masters with conflicting priorities leads to mischief: it creates an opportunity for the entity to play them off against each other and instead follow its own agenda.

At the same time, keeping the distributor-retailers around as the focus of constituent anger is a useful diversionary tactic for both their council-owners, who are no longer

171 The more likely possibility is that at some point the government will propose that they be privatised, a possibility that could lead to the same sorts of problems as occurred in Allconnex's case unless the newly privatised businesses were regulated very carefully.

Section VI.A below discusses the creation of national water pricing principles applicable to Allconnex as part of the National Competition Policy (' $\mathrm{NCP}^{\prime}$ ). The $\mathrm{NCP}$, generally speaking, operates in accordance with the principle of competitive neutrality as part of its push to competitive markets. See generally National Competition Council, Overview, National Competition Policy <http://ncp.ncc.gov.au/pages/overview $>$.

173 In fact, Allconnex reported in its 2011-12 water price monitoring submission to the QCA that recent studies on elasticity of demand 'have found elasticity estimates were generally lower than previously found': Allconnex Water, 'Allconnex Water Price Monitoring Submission 2011-2012' (2011) 99. In other words, raising water prices does not directly correlate with an equivalent reduction in consumption, particularly after consumers have altered their consumption patterns to conserve as much water as they can. Further, Queensland's government has been facing financial difficulties caused in part by water revenue - due to sustained decreased consumption - being less than planned, for which reason SEQ's supposedly 'permanent' water restrictions have recently been removed. 
directly 'responsible' for prices, and for the State government, to the extent that those angry constituents forget that a significant input into the high(er) retail water prices is the higher bulk water charges that the State has imposed. ${ }^{174}$ Apparently the Queensland government thought it was calling the GCCC's bluff by allowing it to withdraw from Allconnex for just this reason. Nor are the Queensland State and local governments alone in contemplating the diversionary value of separate water retailers: the same tactic of letting the water retailer be the focus of consumer anger at higher water prices seems also to be popular in France. ${ }^{175}$

\section{F Enforcing Duties - What Remedies Exist and Who May Seek Them}

Accountability in the form of legal duties is only as valuable as the remedies that exist in the event of breach. Directors' duties may be enforced privately by the company, by its members through a derivative action ${ }^{176}$ or perhaps an oppression action (for example under the ground that the conduct is contrary to the interests of the members of the company as a whole) ${ }^{177}$ or by the public regulator, ASIC.

As noted above, one of the more significant consequences of the distributor-retailers qualifying as corporations for purposes of the Corporations Act is that it opens the door to ASIC enforcing breaches of board members' duties. ${ }^{178}$ That is because, as discussed in Section V.C, the directors' duties set forth at ss 180-183 of the Corporations Act apply to all corporations, not just companies. These sections state that they are civil penalty provisions. ASIC is specifically authorised to enforce civil

174 Cf Grantham, above n 53, 190 ('the board of the GOC acts as a convenient scapegoat to insulate the Minister from bad news').

175 See Giulio Citroni, 'Neither State Nor Market: Municipalities, Corporations and Municipal Corporations in Water Services - Germany, France and Italy Compared' in Hellmut Wollman and Gerard Marcou (eds), The Provision of Public Services in Europe: Between State, Local Government and Market (Edward Elgar Publishing, 2010) 191. Citroni notes the prevalence of 'letting the private sector take at least part of the blame for tariff increases needed to pay for increased investment imposed by stricter environmental regulation' and comments that 'French local politicians thus appear to be willing to "escape" responsibility in the water service sector": 212.

176 An officer or former officer of a company also has standing to seek leave to bring a derivative suit: Corporations Act s 236(1)(a)(ii).

177 Ibid s 232.

178 Derivative and oppression actions under the Corporations Act remain inapplicable to the distributor-retailers since those actions apply only to companies: ss 232 et seq, 236 et seq. 


\section{THE ALLCONNEX WATER DEBACLE}

penalty provisions by applying for a declaration of contravention, pecuniary penalty order, or compensation order. ${ }^{179}$

In addition, in the distributor-retailers' case, the 2010 Regulations provide that a distributor-retailer, a participating local government, 180 or the State can apply to the Supreme Court for a declaration that a board member or officer has breached his or her duties under regs 6-9 of the 2010 Regulations. ${ }^{181}$ The Court can then order the board member to pay compensation for damage suffered by the distributor-retailer, participating local government, the State, 'or another person'. ${ }^{182}$

As can be readily appreciated, board members face much less potential liability (limited to 'compensation') under the 2010 Regulations than under the Corporations Act, where breach of duty may expose directors to orders not only to pay compensation but also to pay additional pecuniary penalties, and even potentially to disqualification from managing corporations. ${ }^{183}$ This is probably the most significant consequence of the distributor-retailers qualifying as corporations.

On the other hand, nothing in the above helps ratepayers who are dissatisfied with a board's management decisions. They technically have no standing under either the Corporations Act or the 2010 Regulations to bring an action for breach of duty, which may be frustrating where ratepayers perceive that their local governments are not responsive enough to their concerns about a distributor-retailer. In fact, however, unhappy customers (who, it should not be forgotten, are also conceptually the distributor-retailers' ultimate owners) may have one option open to them, at least if they can convince the court that the distributor-retailers are corporations for purposes of the Corporations Act: the Corporations Act's statutory injunction provision, s 1324. Section 1324 allows any 'person whose interests have been, are or would be affected' by, inter alia, conduct that constitutes, constituted, or would constitute a contravention of the Act - ie, including breach of directors' duties - to apply for an injunction to restrain the wrongdoer from engaging in the improper conduct.

179

Ibid s 1317J(1); see also Corporations Act ss 1317E, 1317G, 1317H. In addition, s 1317J authorises the corporation itself to apply for a compensation order.

180

Therefore, unlike the Corporations Act's statutory derivative action rules, councils may bring what are effectively derivative actions against board members without being required to obtain prior court approval: cf Corporations Act s 236(1)(b).

2010 Regulations reg 20. Interestingly, reg 20 does not provide a remedy for breach of reg 12 (the duty of confidentiality).

Ibid reg 22. But that other person does not independently have standing to seek compensation; he, she or it is therefore dependent on one of the persons granted standing under reg 20 to file the application.

Corporations Act s 206C. 
Furthermore, s 1324(10) allows the court to order the wrongdoer to pay damages to 'any other person' in addition to or instead of granting the injunction. Section 1324's broad standing provisions and flexible remedies clearly are a potentially powerful tool, although questions remain about the extent to which litigants may use this section to circumvent the restrictions limiting access to other remedies under the Corporations Act. ${ }^{184}$ Furthermore, s 1324's utility is limited by the fact that it will only be useful where there is a potential breach of duty. Unless ratepayers can devise a convincing theory as to why conduct such as, for example, a decision to excessively raise rates constitutes a breach of some directors' duty, s 1324 will provide no relief even though ratepayers may suffer as a result.

If s 1324 is unavailable, then unhappy customers may be left with only one clear option: politics. The Allconnex example illustrates that sustained pressure against politicians who are worried about re-election does have the potential to be effective, at least at the local level where there are fewer issues to distract voters. The increasing ability of disgruntled citizens to connect with each other and publicise their complaints has certainly made those complaints harder to ignore. Further, councils now have an enhanced ability to respond to those complaints in the distributor-retailer context by issuing independent directions. Accordingly, perhaps the lack of remedies that ratepayers may seek directly from the distributor-retailers is not so alarming after all. But generalised to other GBEs, particularly those operating at the state level, it may still be hard for citizens to convince government officials to respond to their concerns and rein in offending GBE conduct (where possible) unless those citizens can somehow convince the government that its failure to correct the problem will become a significant election issue.

Despite the increasing ability of citizens to publicise their complaints and pressure relevant members of the government, there still might be situations where the council-owners ignore their constituents. What then? Could aggrieved citizens bring something akin to an oppression suit? Probably not. The oppression provisions under the Corporations Act apply only to companies, which excludes the distributorretailers, and the 2010 Regulations contain no provisions allowing for the same. Even if a court were willing to entertain such an action under the general law, members of the public would have great difficulty establishing standing. Oppression suits are traditionally brought by company members, ${ }^{185}$ whereas no members of the public are members of Allconnex, except in the most diffuse sense that the distributor-retailers

\footnotetext{
184 Compare, eg, Mesenberg v Cord Industrial Recruiters Pty Ltd (1996) 19 ACSR 483, 488-91 with Airpeak Pty Ltd v Jetstream Aircraft Ltd (1997) 23 ACSR 715, 719-21. 


\section{THE ALLCONNEX WATER DEBACLE}

are, ultimately, owned by the public. ${ }^{186}$ The same problem applies in the case of other GBEs.

The only remaining argument arises under the public trust theory, where ratepayers could attempt to argue that a distributor-retailer is breaching a fiduciary duty to the ratepayers by not adequately considering their interests in its decision-making. Such was essentially the holding in Bromley London Borough Council v Greater London Council. ${ }^{187}$ In that case, the Greater London Council ('GLC') required subsidiary borough councils to raise rates to fund a public transport fare cut. The GLC refused to reconsider its decision even after learning that the costs to ratepayers would be double the amount of the fare cut because of a loss of block funding from the UK government if the fare cut went ahead. One of the borough councils sued, partially on the ground that the GLC had a fiduciary duty to have regard to ratepayers' interests. The duty required the GLC to engage in a balancing test between the competing constituencies (ratepayers versus farepayers) instead of disregarding all costs to the ratepayers. The House of Lords upheld the Appellate Court's finding of breach of fiduciary duty. As Lord Diplock stated:

It is well established ... that a local authority owes a fiduciary duty to the ratepayers from whom it obtains moneys needed to carry out its statutory functions, and that this includes a duty not to expend those moneys thriftlessly but to deploy the full financial resources available to it to the best advantage ... [T] he GLC had a discretion as to the proportions in which that total financial burden should be allocated between passengers and ratepayers. What are the limits of that discretion and whether those limits would have been exceeded if the only effect of the GLC's decision to instruct the [London Transport Executive] to lower its fares by 25 per cent had been to transfer to the ratepayers the cost $\ldots$ is a difficult question on which the arguments for and against are by no means all one way. Fortunately I do not find it necessary to decide that question in the present appeals ... because the GLC's decision was not simply about allocating a total financial burden between passengers and the ratepayers, it was also a decision to increase that total burden so as nearly to double it and to place the whole of the increase on the ratepayers.... That would, in my view, clearly be a thriftless use of moneys obtained by the GLC from ratepayers and a deliberate failure to deploy to the best advantage the full financial resources available to it by avoiding any action that would involve forfeiting grants from central government funds. It was thus a breach of the fiduciary duty owed by the GLC to the ratepayers. ${ }^{188}$

\footnotetext{
186 Hughes Aircraft Systems International v Airservices Australia (1997) 76 FCR 151, 196.

187 [1983] 1 AC 768.

188 Ibid 829-30.
} 
There are several problems, however, with applying this theory in Australia. First, it requires an extreme level of disregard for the ratepayers before a public entity will be found to be in breach. Furthermore, no Australian court has yet held that such a duty exists in Australia. ${ }^{189}$ Perhaps the closest we have seen is Finn J's decision in Hughes Aircraft Systems International v Airservices Australia, in which he noted that:

There is, I consider much to be said for the view that, having no legitimate private interest in the performance of its functions, a public body (including a state owned company) should be required as of course to act fairly towards those with whom it deals at least insofar as this is consistent with its obligation to serve the public interest (or interests) for which it has been created. ${ }^{190}$

But agreeing that such an obligation exists in the abstract and finding that there is a legally enforceable fiduciary duty to ratepayers are two different propositions, and even Justice Finn warns that it would be very difficult to find such a duty under existing Australian trust and fiduciary law. ${ }^{191}$ This is why any enhanced duty to the public must be written into a statute such as the 2010 Regulations rather than left to the courts to be discovered. ${ }^{192}$

\section{G 'Soft' Law/Self-Regulation}

In addition to the legal requirements mentioned above, various 'soft', self-regulatory mechanisms help ensure that companies are managed appropriately. ${ }^{193}$ These 'soft' mechanisms include stock exchange listing rules, accounting standards, mandatory industry codes of conduct, and voluntary 'if not, why not' codes including the ASX Corporate Governance Principles and voluntary industry codes. ${ }^{194}$ Some of these tools will be less useful or simply inapplicable in the case of the distributor-retailers due to their status as government-owned, non-traded entities. For example, the ASX Corporate Governance Principles do not apply to the distributor-retailers since they are not companies listed on the ASX.195

189 Paul Finn, 'Public Trusts, Public Fiduciaries' (2010) 38 Federal Law Review 335, 348; IW v City of Perth (1997) 191 CLR 1, 49.

$190 \quad$ (1997) 76 FCR 151, 196.

191 Finn, 'Public Trusts, Public Fiduciaries', above n 189, 348-49.

192 See generally ibid 350-51.

193 See Farrar, above n 40, 4, 374; see also Jason Harris, Anil Hargoven and Michael Adams, Australian Corporate Law (LexisNexis Butterworths, $3^{\text {rd }}$ ed, 2011) 403; Jason Harris, Company Law: Theories, Principles and Applications (LexisNexis Butterworths, 2012) 170.

$194 \quad$ Farrar, above n 40, 374-87.

195 See ASX Corporate Governance Principles, above n 85. Indeed, the principles are not mandatory even in the case of companies listed on the ASX. But ASX Listing Rule 4.10.3 requires listed companies that have not followed all of the recommendations to include a 


\section{THE ALLCONNEX WATER DEBACLE}

Discipline is also exerted on corporate boards through the workings of various markets including the product market, in which competition pushes companies to produce and sell better products at lower cost; the market for managerial services, which rewards good managers with jobs and punishes bad managers with a lack of employment; the market for corporate control, which 'disciplines managers with the threat of replacement' by takeover; and the debt markets, in which poorly managed companies may have to compensate for their relative riskiness by paying more for money they borrow. ${ }^{196}$

The distributor-retailers, however, are in large part exempt from these market forces. The workings of the product market are inapplicable since the distributor-retailers have no competitors and sell a product that all property-owners must buy. ${ }^{197}$ The managerial services market may be less efficient since some of the criteria by which managerial conduct tends to be judged (eg, share price movement) will be lacking. The market for corporate control is totally absent since (under current law, at least) it is not possible for anyone to buy the councils' shares and take over a distributorretailer. ${ }^{198}$ The debt markets may not accurately reflect the risk of loaning to the distributor-retailer if creditors believe that the loan is 'effectively guaranteed by the state'. 199

Accordingly, it appears that the soft law mechanisms that help constrain the conduct of private sector businesses are in large part irrelevant to the governance of GBEs, in particular Allconnex.

\section{PRICING Issues}

This article has previously made the point that the distributor-retailers, as public entities, should be obligated to act in the public interest. Assuming one agrees with this perspective, there is still the question of how this sentiment can be implemented in practice. Section $\mathrm{V}$ discussed ways to incorporate more of a public focus into the

statement in their annual report 'identify[ing] those recommendations that have not been followed and giv[ing] reasons for not following them.'

197 See Explanatory Notes, Queensland Competition Authority Bill 1997 (Qld) 2 ('monopoly or near monopoly GBEs possess considerable discretion over the prices they charge for their outputs, since competitive pressures do not operate to constrain an entity's pricing activities. In addition, these entities are not subject to the same intense pressures to produce efficiently that drive organisations in competitive environments.'). Cf Grantham, above n 53, 192.

198 Cf Grantham, above n 53, 193.

199 Farrar, above n 40, 469. 
duties imposed on board members. This section examines the pricing issues that were the root cause of Allconnex's problems and how, specifically with regard to pricing, Allconnex could have been made to be more responsive to the public's concerns.

Perhaps the cleanest way to require GBEs to keep costs affordable, at least to particularly vulnerable members of the population, is through the imposition of community service obligations ('CSOs'). GBEs - in particular, GOCs - are often subject to CSOs. The GOC Act defines CSOs as 'obligations to perform activities that the GOC's board establishes ... are not in the commercial interests of the GOC to perform' that arise as a result of a direction given by the shareholding ministers or a statutory duty to perform the activity. ${ }^{200}$ As a Tasmanian government document explains, '[a] CSO is created when a Council requires a significant business activity to undertake a non-commercial function in order to achieve a Council policy objective.' ${ }^{201}$ A GOC's community service obligations are to be specified in its statement of corporate intent, ${ }^{202}$ and typically include obligations such as to provide a service to lower income groups at a subsidised price or in a rural area where it would not make commercial sense to do so. ${ }^{203}$ Under the GOC Act, the state government may (and in fact would normally be expected to) ${ }^{204}$ compensate the GOC for the cost of performing the CSOs, just as the new rules regarding individual directions require the relevant council to compensate the distributor-retailer for losses incurred as a result of complying with the direction. ${ }^{205}$

\section{A The Missing Requirement to Focus on Price Control}

Allconnex does not seem to have been subjected to any CSOs. Nor, despite operating as a monopolist with no competitive pressure to keep prices palatable, was Allconnex explicitly required to take steps to control the price that it charged for water. This can

200 GOC Act s 112. For a critique of the GOC Act's CSO provisions, see Darryl D McDonough, 'Corporate Governance and Government Owned Corporations in Queensland' (1998) 10(2) Bond Law Review 272, 283-5.

Tasmanian Department of Premier and Cabinet Local Government Division, 'Community Service Obligation Policy and Guidelines for Local Government in Tasmania' (November 2000) 3 <http://www.dpac.tas.gov.au/_data/assets/pdf_file/0007/46384/Community_ service_obligations.pdf $>$. GOC Act s 113(1).

203 See generally Queensland Treasury Department, 'Community Service Obligations: A Policy Framework' (March 1999) <http://www.treasury.qld.gov.au/office/knowledge /docs/community-service/community-service.pdf>. Ibid 4-5.

205 GOC Act s 113(2) and (3). See Section V.E.2 above. 


\section{THE ALLCONNEX WATER DEBACLE}

be compared with the former situation in the Australian Capital Territory, where the territory-owned ACTEW Corporation Ltd, which provides water supply and sewerage services in the ACT, was formerly required to make its service charges 'as low as practicable having regard to the revenue required for the maintenance of its affairs on a sound commercial basis' ${ }^{206}$ The lack of focus on competitive pricing at Allconnex also stands at odds with the requirement at the Commonwealth level that Commonwealth government business entities acting as monopolists must consider price control strategies as part of their yearly corporate planning requirement. ${ }^{207}$ In contrast, the only direction in Allconnex's governing documents that had any bearing on pricing was a requirement that Allconnex, despite its position as a monopolist, maximise returns to its shareholders ${ }^{208}$ - a fact that Allconnex's board used to justify large increases in the price of water on at least one occasion. ${ }^{209}$

The only other legal requirement regarding pricing applicable to the distributorretailers appears to be found in the Financial and Performance Management Standard 2009 (Qld) ('FPMS'), which applies to departments and statutory bodies. The FPMS

206 DE Fisher, Water Law (LBC Information Services, 2000) 235, citing the Energy and Water Act 1988 (ACT) s 50(4) (which has since been superseded by the Utilites Act 2000 (ACT)). The current version of the Utilities Act 2000 (ACT) does not discuss the pricing of water services other than to require capital contribution charges to be in accordance with industry codes (see s 101), but instead allows the Minister to give written direction of CSOs that the water utility is to undertake, including to provide services at reduced or no cost, on the condition that any compliance costs be borne by the Treasurer: ss 219, 223. The problem with this approach is that it does not address the bigger issue that government monopolies should act as prudent stewards of the funds to which they have access. Commonwealth Authorities and Companies Regulations 1997 (Cth) reg 6AAA(k); Commonwealth Authorities and Companies Act 1997 (Cth) s 17(6).

Participation Agreement $5 \mathrm{cl}$ 3(d) (Business Objectives). Allconnex's business objectives were set out as follows: '3. Business Objectives: The Authority must carry out its functions for its geographic area as required under section 11 of the Distribution and Retail Restructuring Act [the 2009 Act] in a way that is consistent with the following objectives: (a) to be a best practice water industry leader; (b) to operate using the principles of excellence in governance, economy, environment, social responsibility and public health; (c) to provide the Water and Wastewater Services required to support the communities (including growth) of the participating local governments; (d) to deliver optimal returns on investment to the Participants; (e) to provide excellence in customer service; (f) to be an employer of choice; and (g) to proactively contribute to developments in the water industry' (emphasis added).

See Allconnex Water, above n 130. 
requires entities that charge users for goods or services to 'consider' a number of factors including whether:

- 'the users have the capacity to pay for the goods or services'; and

- 'the users have a choice whether to accept the goods or services'; and

- 'the goods or services are available from a supplier other than [the] statutory body'; and

- 'the goods or services are supplied for the benefit of the general public or for the benefit only of users who do not have the capacity to pay'; and

- 'charging for the goods or services improves, or may improve, resource allocation through more economical use of the goods or services'. ${ }^{210}$

The FPMS also requires the distributor-retailers to 'have regard to the full cost of providing the goods or services', 211 but allows them to charge less than the full cost if 'satisfied that the lower cost is appropriate'. ${ }^{212}$ So, the FPMS requires the distributorretailers to 'consider' the facts that they are (a) monopolists (b) selling a necessary good that all landowners must pay for; and (c) which is supplied for the benefit of the general public, but it does not require them to adjust or contain their prices as a result. Nor does it require them to maintain high prices to encourage water conservation, although that, too, is a factor that may be considered. In this author's view, the FPMS should have had a greater influence on Allconnex's pricing decisions than appears to have been the case (at least to the extent that the factors identified as (a), (b), and (c) above appear to have been ignored). Accordingly, while its delineation of factors to be considered certainly is useful, the FPMS cannot be said to have been a real constraint on Allconnex's pricing determinations.

Furthermore, in 1994 the Council of Australian Governments ('COAG') agreed to a water reform framework that, among other things, required urban water retailers to commence consumption-based pricing on water bills where cost effective to do so and, generally speaking, to fully pass on the cost of water to consumers. ${ }^{213}$

\footnotetext{
210 Financial and Performance Management Standard 2009 (Qld) s 18(1).

211 Ibid s 18(2).

212 Ibid s 18(3).

213 Council of Australian Governments, 'Communiqué on Water Resource Policy' (25 February 1994) ('1994 COAG Communiqué'). As to the status of this document, it is useful to note that, according to the COAG website, ' $[t]$ he outcomes of COAG meetings are contained in communiqués released at the end of each meeting. Where formal agreements are reached, these may be embodied in intergovernmental agreements...' Under the 1994 COAG Communiqué, 'where service deliverers are required to provide
} 


\section{THE ALLCONNEX WATER DEBACLE}

Specifically, the COAG framework required urban water retailers to implement new charging arrangements using a two-part tariff 'comprising an access or connection component together with an additional component or components to reflect usage.'214 As the National Competition Council ('NCC') explains, '[ $t$ ]he purpose of the usage based component is to ensure that water users face appropriate incentives to better manage water consumption.'215

Developments since 1994 have entrenched the two-part tariff regime in Queensland and elsewhere in Australia. First, at an April 1995 COAG meeting, the Commonwealth, States and Territories agreed to a program to implement the National Competition Policy ('NCP') and related reforms, including the $1994 \mathrm{COAG}$ water reform framework. Under this agreement, signatories would face the loss of significant Commonwealth government funding to the extent that they did not comply with the 1994 water reform principles. ${ }^{216}$ Governments' compliance with the NCP is assessed by the NCC, which can recommend that payments to state or territory governments be reduced to the extent of any non-compliance. For example, as a result of the NCC's recommendation, the Federal treasurer withheld $\$ 540,000$ in payments to Queensland for 2001-02 and 2002-03 due to Townsville's noncompliance with the consumption-based pricing requirement, although the NCC ultimately agreed to recommend that the withheld funding be restored after Townsville was able to establish, in line with the requirements of the 1994 COAG communiqué, that consumption-based pricing would not be cost effective. ${ }^{217}$

The 1994 water reform principles now also form part of the National Water Initiative ('NWI'), agreed to at a June 2004 COAG meeting, to which Queensland is also

water services to classes of customer at less than full cost, the cost of this [is to] be fully disclosed and ideally paid to the service deliverer as a community service obligation': 1994 COAG Communiqué at [3(a)(ii)]. See also National Competition Council, 'Water Reform in Queensland: Water Pricing by Townsville City Council' (National Competition Policy Supplementary Assessment, April 2003) ('2002 NCP Supplementary Assessment’). 1994 COAG Communiqué, above n 213, [3(b)(i)].

2152002 NCP Supplementary Assessment, above n 213, 2. Ironically, some of the more recent data on elasticity of demand among water consumers seems to call into doubt the assumption that clearer price signals will lead to a significantly greater reduction in consumption. It appears that there is a natural floor beyond which water consumption cannot, consistent with health and good hygiene, drop no matter how high prices rise: see, eg, Allconnex Water, 'Allconnex Water Price Monitoring Submission 2011-2012', above $\mathrm{n}$ 173, 99.

216 Agreement to Implement the National Competition Policy and Related Reforms (signed 11 April 1995) 3.

$217 \quad 2002$ NCP Supplementary Assessment, above n 213. 
bound. ${ }^{218}$ As part of the NWI, a National Water Commission ('NWC') was created, which is now responsible for assessing governments' implementation of the COAG water reforms. ${ }^{219}$ The NWC periodically reports to COAG on the progress of water reform. 220

Under the NWI, metropolitan areas are expected to move to upper bound pricing, defined as:

The level at which, to avoid monopoly rents, a water business should not recover more than the operational, maintenance and administrative costs, externalities, taxes or tax equivalent regimes, provision for the cost of asset consumption and cost of capital, the latter being calculated using a weighted average cost of capital. 221

This can be contrasted with lower bound pricing, which is the minimum necessary for a business to recover its costs and be viable.222 This push to move from lower bound pricing (or pricing even below lower bound pricing) to upper bound pricing effectively constitutes a policy decision to raise water prices. As a matter of principle, this author believes that policymakers should reconsider what, in this author's view, is an unfortunate decision to make a profit from a necessary good, water. It is unclear why lower bound pricing (ie, simply covering one's costs) should not be adequate. It is suggested that the general public, for whom the government is supposed to act, is broadly disgusted with the notion of governments seeking to make a profit from government monopoly businesses, particularly in the case of water. Governments' attempts to use ratepayers as a piggy bank turn the notion of a governmental obligation to act in the public interest on its head.

The water reform principles including the push to upper bound pricing and the twopart tariff requirement were intended to, among other things, encourage water conservation. However, the two-part tariff rule may be having an opposite effect, at least if public feedback in the media is anything to go by. The practical effect of the

218 Intergovernmental Agreement on a National Water Initiative (signed 25 June 2004) ('2004 Intergovernmental Agreement') [6]. Note that Tasmania and Western Australia have since joined the Agreement: see NWC, National Water Initiative <http://www.nwc. gov.au/nwi>. See National Water Commission <http://www.nwc.gov.au>.

220 Ibid.

221 Department of the Environment, Water, Heritage and the Arts, 'National Water Initiative Pricing Principles Regulation Impact Statement' (Australian Government, February 2010) ('Pricing Principles Regulation Impact Statement') 2-4.

222 NWC, Term Definition: Lower Bound Pricing <http://dictionary.nwc.gov.au/water_ dictionary/item.cfm?id=634\&cRefer $=5 \&$ sefer $=0>$. 


\section{THE ALLCONNEX WATER DEBACLE}

two-part tariff requirement is that Queensland water bills now separately break out not only State bulk/wholesale water costs (ie, the cost at which the State government sells water to the water retailers) from the water retailer's retail price, but further break out, as part of the retailer price, the consumer's specific water usage charges from the water retailer's fixed water and sewerage access charges, which apply unchanged no matter how little water a consumer uses. ${ }^{223}$ Rather than highlighting the consumer's ability to lower his or her water bill by reducing consumption, breaking out the fixed charges from usage charges in consumers' water bills instead makes clear what a small percentage of a typical water bill is actually related to water usage. This would seem to provide a disincentive to average residential consumers to change their consumption patterns, since it is obvious how little an effect the consumer's efforts would have on reducing the bill. This is especially ironic considering that an intended outcome of the 2004 Intergovernmental Agreement on a National Water Initiative was to 'avoid perverse or unintended pricing outcomes'.224

Furthermore, although NWI Pricing Principle 1 now provides for water businesses to recover only 'efficient costs consistent with the NWI definition of upper bound' revenue, unlike previous principles that did not limit cost recovery to efficient costs, ${ }^{225}$ none of the water reforms impose upon the states any true legal requirement to be careful in how they spend on water infrastructure. For example, the NWI Pricing Principles are merely a 'set of guidelines' or 'road map' for pricing practices. ${ }^{226}$ In Queensland, in particular, there is no real control on the government's ability to raise bulk water prices except the threat of defeat at the polls, which threat may or may not be effective depending on what other issues are capturing the public's attention. In fact, in Queensland it was the government's decision to spend nearly $\$ 7$ billion on infrastructure that caused bulk water prices to rise so much. ${ }^{227}$

Moreover, until its recent amendment in November 2012, Queensland's Water Act 2000 (Qld) ('Water Act') required water to be delivered 'at the lowest overall cost', 228 but that requirement was directed to the wrong entity. That direction was imposed solely on the Queensland Water Commission ('QWC'). ${ }^{229}$ But the QWC itself did not

\footnotetext{
223 See Queensland Water Commission, 'CPI Cap and Residential Bills Fact Sheets' (on file with author).

225 Pricing Principles Regulation Impact Statement, above n 221, 43.

226 Ibid 36.

227 Queensland Commission of Audit, Interim Report June 2012 (2012) 173, 175.

Water Act 2000 (Qld) s 346(3)(b)(ii). The Water Act was amended, repealing this provision, in late November 2012.

229

Ibid.
} 
sell water, although it did make recommendations with regard to the price of bulk water. ${ }^{230}$ Although the 'lowest overall cost' requirement did not apply to any actual water retailer at the time the Allconnex dispute was taking place, it was reported in late June 2012 that the QWC and the State's bulk water suppliers ${ }^{231}$ would be merged into one 'super-supplier' of bulk water by the end of 2012, ${ }^{232}$ which meant that this error could have been fixed and this requirement given new teeth. New legislation was in fact passed in late November 2012 that provided for the 1 January 2013 merger of Queensland's bulk water retailers and the abolition of the QWC. ${ }^{233}$ Unfortunately, the legislation abolished the 'lowest overall cost' language instead of directing it to an entity that actually sells water - ie, the new bulk water 'super-supplier', which has taken over the name Seqwater. It is suggested that the 'lowest overall cost' standard be re-introduced and directed to the new Seqwater.

\section{B The Queensland Competition Authority's Limited Ability to Influence Pricing}

As an entity engaged in business activities on behalf of the government (and in particular one that is doing so as a monopolist), Allconnex was subject to the oversight of the QCA, which was authorised to investigate Allconnex's pricing practices. ${ }^{234}$ In conducting investigations, the QCA is instructed to have regard, inter alia, not only to the 'appropriate rate of return on assets', but also to 'the protection of consumers from abuses of monopoly power' and 'social welfare and equity considerations including community service obligations, the availability of goods and services to consumers and the social impact of pricing practices'. ${ }^{235}$ The QCA is also directed to have regard to environmental issues and the government's need to

See, eg, Queensland Water Commission, 'Annual Report' (2010-11) 20-21.

Seqwater, Linkwater, and the SEQ Water Grid Manager.

Mark Solomons, 'Queensland Government to Announce Restructure of Southeast's Bulk Water Companies into One Super-Supplier', The Courier-Mail (online), 26 June 2012 $<$ http://www.couriermail.com.au/news/queensland/queensland-government-toannounce-restructure-of-southeasts-bulk-water-companies-into-one-supersupplier/story-e6freoof-1226408308100>.

See South East Queensland Water (Restructuring) and Other Legislation Amendment Act 2012 (Qld).

Queensland Competition Authority Act 1997 (Qld) ('QCA Act') ss 23, 23A; Queensland Competition Authority Regulation 2007 reg 2A (declaring Allconnex's government business activity of providing water and sewerage services a monopoly business activity for purposes of s 20(1) of the QCA Act).

QCA Act s 26(c), (e), (i). 


\section{THE ALLCONNEX WATER DEBACLE}

take steps to guarantee adequate supply. ${ }^{236}$ The principles that the QCA is to take into account therefore reflect not only the need to ensure supply but also to accommodate the need for such a vital resource to be affordable.

It is questionable, however, whether an entity has much to fear even from a QCA finding of price-gouging, because the QCA has no independent power to rein in the inappropriate pricing practices. Originally the QCA was going to be responsible for setting the distributor-retailers' prices starting in 2013, 237 but this pricing determination power was revoked. ${ }^{238}$ As a result, the QCA's powers are limited to reporting on the results of its investigation to the ministers charged with administering the QCA Act and making any recommendations that it sees fit as a consequence of that investigation. ${ }^{239}$ It is then up to those ministers to act on the QCA's findings, but the ministers are expressly granted the power to reject some or all of them. ${ }^{240}$ The ministers administering the QCA Act must refer any of the QCA's

236 See, eg, s 26(e) (QCA to have regard to the appropriate rate of return on assets); s 26(g) (have regard to the impact on the environment of prices charged by the government agency); and s 26(k) (have regard to legislation and government policies relating to ecologically sustainable development). Section 26(2), furthermore, provides that '[i]f the investigation relates to a monopoly business activity involving the supply of water, the authority must have regard to water pricing determinations and water supply determinations.'

See, eg, Allconnex Water, 'Infrastructure, Bulk Water Behind Water Price Increases', above $\mathrm{n} 17$ (noting that, commencing 1 July 2013, the QCA will determine water prices). Fairer Water Prices for SEQ Amendment Act 2011 (Qld) s 5. Interestingly, the QCA Act still contains sections foreshadowing a more robust QCA ability to make pricing 'determinations' if water retail is privatised in the future: QCA Act pt 5A sub-div 7. The current section in the QCA Act applies only to monopoly water supply activities carried out by 'water suppliers', which are defined in the QCA Act's Dictionary (sch 2) as 'an entity, other than the State or a government agency', that, inter alia, 'is not owned, whether legally or beneficially and whether entirely or in part, by the State or a government agency.' In other words, this more robust pricing determination power will only apply to private water retailers, and the QCA Act does not say when it will become effective. The author is not aware of the existence of any non-government water retailers in Queensland at present. Clearly, however, this 'determination' power applies neither to the remaining distributor-retailers nor to any of the local councils that resumed responsibility for the sale of water from Allconnex. QCA Act ss 30, 33.

Ibid s 36. The ministers do need to provide reasons for whatever decision they make: $\mathrm{s}$ 36(4). Note that the local councils have the same power to ignore the QCA's recommendations about pricing practices since their resumption of control over water sales: s 36A. 
recommendations that they accept either in toto or with qualifications to the relevant portfolio minister. ${ }^{241}$ But, again, the QCA Act does not then require the portfolio minister to actually do anything in particular with the recommendation. The portfolio minister appears free (from a legal standpoint, at least) to ignore the QCA's findings and recommendations, making the whole exercise potentially meaningless unless there is corresponding political pressure on the portfolio minister to act. If the political situation favours ignoring the QCA's findings, then the portfolio minister presumably will do so, ill effects on consumers be damned.

In any event, the QCA's price monitoring investigations of Allconnex's pricing practices themselves never considered, on a holistic basis (for example, by taking into account concerns such as the fact that water is a necessary good for all members of the community and hence must remain affordable), the overall appropriateness of the price that Allconnex was charging for water. The QCA focused instead on whether, based on various mathematical formulae, Allconnex's price increases made sense compared to Allconnex's capital and operating costs. ${ }^{242}$ It is perhaps cold comfort that the QCA was doing the same thing even when the GCCC was selling its own water. Indeed, in its October 2009 Final Report on Retail Price Monitoring in SEQ Urban Water Sector - GCCC, the QCA made clear that '[t]he Authority is not required to verify that prices are appropriate in terms of regulatory pricing principles or to recommend changes in prices' ${ }^{243}$ It stated that its role was 'limited to reporting the pricing information that explains changes in retail water prices'. ${ }^{244}$ This is exactly what the QCA did when it investigated Allconnex's pricing, which raises the question: if not the QCA, then who is verifying that monopoly water sellers' prices are fair or appropriate?

\section{Concrete Steps to Limit Prices Were Too Little, Too Late}

Ironically, once the government decided to allow participating local governments to pull out of their distributor-retailers, Parliament enacted legislation restricting retail water price rises (but not the price of bulk water) to the consumer price index (CPI) for a two-year period through to 30 June 2013.245 Furthermore, local governments

\footnotetext{
$241 \quad$ Ibid s 37.

242 See, eg, QCA, 'Final Report: SEQ Interim Price Monitoring Part A - Overview' (March 2012) 1; QCA, 'Final Report: SEQ Interim Price Monitoring for 2011-12 Part B - Detailed Assessment' (March 2012) 120.

243 QCA, above $\mathrm{n} 15,3$.

244 Ibid (emphasis added).

245 See new ch 2A pt 3 div 1 to the 2009 Act, set forth in the Fairer Water Prices for SEQ Amendment Act 2011 (Qld) and effective from 1 July 2011. See in particular 2009 Act ss 53ARC, 53ARD. See generally Bligh, above $\mathrm{n} 1$.
} 
were required to adopt a 'price mitigation plan' 'about how the local government propose[d] to mitigate the impact on customers for relevant charges after the capped prices period ends', ${ }^{246}$ although this requirement has since been repealed by the new government as part of the recent legislative changes to the water regime. ${ }^{247}$ Among other things, the now-repealed price mitigation plan would have required the local governments to explain 'the extent to which a distributor-retailer's profits that are paid to the participating local government are to be used to provide subsidies or rebates to users of water services or wastewater services.' ${ }^{248}$ Surely it would have been easier to just include a requirement for the actual sellers of water not to charge impracticably high prices in the first place, as is included in the Commonwealth's Commonwealth Authorities and Companies Act s 17(6)(k).

In late June 2011 Allconnex announced that it would voluntarily extend the CPI cap to not just the residential and small business customers covered by the government's plan, but to all customers. ${ }^{249}$ However, the belated attempts on the part of the government and Allconnex to address consumer anger over large increases in water prices were too little, too late. If the government had imposed price caps before Allconnex sent its first bills, the outcry that led to Allconnex's demise likely never would have happened. Alternatively, rules requiring Allconnex to take into account public concerns (such as those proposed above) might have led to the same result. Rules restricting Allconnex, a monopolist, from imposing precipitous price rises should have been in place before the date that the distributor-retailers took over water sales from the local councils.

\section{CONCLUSION}

Allconnex's corporate governance structure was ultimately ineffective because Allconnex was accountable to different people for different things, and because no one person or entity had the ultimate power to override Allconnex's board. Allconnex's fractured corporate governance structure meant that not only was accountability split between the councils and the State, but some areas simply fell through the cracks, with Allconnex ultimately accountable to neither the councils nor the portfolio minister. One such area was pricing policy, which was the responsibility of Allconnex's management and board. So when pricing became an issue, no one

\footnotetext{
2462009 Act s 99BW (now repealed).

247 South East Queensland Water (Restructuring) and Other Legislation Amendment Act 2012 (Qld) s 14.

2482009 Act s 99BW(2)(d) (now repealed).

249 Allconnex Water, 'New Allconnex Water Charges Extend Government CPI Cap to Every Customer' (Media Release, 28 June 2011).
} 
could easily intervene, although Parliament did belatedly pass a law restricting Allconnex's ability to raise prices. If Allconnex's shareholders, or even simply its majority shareholder, the GCCC, could have frozen or limited the price rises imposed on Gold Coast water customers, then the GCCC would not have felt the need to withdraw from Allconnex and Allconnex would continue to exist today.

It is true that the council-owners retained reserve powers to interfere with Allconnex's management where it was both 'necessary' and 'in the public interest' to do so. Reserve powers are not a panacea, however, because there is an expectation that they will only be used in extreme circumstances. The requirement that the exercise be 'necessary' further restricts their availability. Furthermore, they were likely useless in the instant case because Allconnex was governed as a tyranny of the minority whereby the majority shareholder, the GCCC, could not utilise the councils' reserve powers unless both of the minority councils agreed. Recent changes to the law to allow individual council-owners of the two remaining distributor-retailers to block price rises within their local government area, while too late for Allconnex, are a positive development and would seem to indicate some level of agreement with this analysis.

Other corporate and public sector governance mechanisms that help align private and public sector managers' interests with those of their owners and the public, such as the existence of directors' duties with personal liability attaching in case of breach, various administrative law remedies, and the workings of the market were either insufficient to restrain Allconnex's management or inapplicable. As a result, the situation eventually became so heated that Allconnex's demise was perhaps inevitable.

The failure of an entity like Allconnex is self-evidently something that should be avoided not only because of the waste of money and effort but because of the harm that it causes to the institutions of government. There is a reputational or institutional cost that is no less dangerous for all that it is hard to measure. The creation of an overarching obligation to consider the needs and concerns of the public may provide an important safety net allowing for GBEs to self-correct before it is too late. This article therefore proposes the introduction of a statutory duty on distributor-retailers' board members to have regard to the interests of stakeholders including, in particular, the council-owners and their constituents. Such a duty also might assist in the case of other GBEs.

Allconnex's failure was specifically a result of widespread anger over its pricing strategy. Since Allconnex was a monopolist selling a necessary good, unhappy customers could not simply walk away but instead were dependent on the regulatory regime to come to their assistance. However, the pricing regime applicable 
to Allconnex suffered three critical deficiencies. First, Allconnex, unlike many other government business entities, was not instructed to keep prices as low as possible. Second, the regulator with investigatory powers over the distributor-retailers' pricing lacks teeth. Finally, the Queensland government waited too long before finally imposing short-term price controls, and Allconnex's copycat decision to extend the scope of the price controls was too little, too late.

A deficient pricing regime combined with a deficient governance regime brings us full circle. In combination, they led to disaster. Simply put, Allconnex's demise could have been avoided if Allconnex's board had been required to pay more heed to the needs of Allconnex's end customers. This oversight in the statutory framework was a missed opportunity to emphasise to Allconnex's board and management the need to restrain unnecessary price increases. It was inevitable that the creation of an entity tasked with 'deliver[ing] optimal returns on investment to the Participants' 250 in which no emphasis was placed on the need to keep prices under control - for a commodity that all members of the community must buy, and in monopoly circumstances - or otherwise heed citizen concerns would lead to citizen outrage and political turmoil. Proposals such as the creation of a duty to the public and a greater emphasis on controlling GBE monopoly power might provide a solution. 